\title{
HAS THE DISPLACEMENT OF OLDER WORKERS INCREASED?
}

\author{
Alicia H. Munnell, Steven Sass, Mauricio Soto, and Natalia Zhivan
}

CRR WP 2006-17

Released: September 2006

Draft Submitted: September 2006

\author{
Center for Retirement Research at Boston College \\ 258 Hammond Street \\ Chestnut Hill, MA 02467 \\ Tel: 617-552-1762 Fax: 617-552-1750 \\ http://www.bc.edu/crr
}

* Alicia H. Munnell is the Director of the Center for Retirement Research (CRR) and the Peter F. Drucker Professor of Management Sciences at Boston College's Carroll School of Management. Steven Sass is the Associate Director for Research at the CRR. Mauricio Soto is an Economics graduate student at Boston College and a senior research associate at the Center. Natalia Zhivan is a graduate research assistant at the Center. The research reported herein was pursuant to a grant from the U.S. Social Security Administration (SSA) funded as part of the Retirement Research Consortium (RRC). The findings and conclusions expressed are solely those of the authors and do not represent the views of SSA, any agency of the Federal Government, the RRC, or Boston College. The authors would like to thank Robert Hutchens for very useful comments and Madeline Zavodny for generously sharing her knowledge, experience, and files. They would also like to thank Francesca Golub-Sass and Jerilyn Libby for excellent research assistance and Kelly Haverstick for helping us untangle our equations.

(C) 2006, by Alicia H. Munnell, Steven Sass, Mauricio Soto, and Natalia Zhivan. All rights reserved. Short sections of text, not to exceed two paragraphs, may be quoted without explicit permission provided that full credit, including (C) notice, is given to the source. 


\title{
About the Center for Retirement Research
}

The Center for Retirement Research at Boston College, part of a consortium that includes a parallel centers at the University of Michigan and the National Bureau of Economic Research, was established in 1998 through a grant from the Social Security Administration. The goals of the Center are to promote research on retirement issues, to transmit new findings to the policy community and the public, to help train new scholars, and to broaden access to valuable data sources. Through these initiatives, the Center hopes to forge a strong link between the academic and policy communities around an issue of critical importance to the nation's future.

\author{
Center for Retirement Research at Boston College \\ 258 Hammond Street \\ Chestnut Hill, MA 02467 \\ phone: 617-552-1762 fax: 617-552-0191 \\ e-mail: crr@bc.edu \\ http://www.bc.edu/crr
}

\section{Affiliated Institutions:}

American Enterprise Institute

The Brookings Institution

Center for Strategic and International Studies

Massachusetts Institute of Technology

Syracuse University

Urban Institute 


\begin{abstract}
The employment of older workers into their mid-60s will be critical to their ability to ensure a secure retirement. One of the risks threatening the ability to work to older ages is being "displaced," with displacement defined as the elimination of the worker's job due to a shift in the demand for labor. Displacement can easily throw 50-year-old workers off course, disrupt their retirement saving plans, and lead to premature retirement.

This paper explores the relationship between job loss and age over the period 1984-2004 using the biennial Displaced Worker Supplement to the Current Population Survey. It finds that no major trends in the displacement of older workers have occurred over the 11 Displaced Worker Surveys conducted during the period. Re-employment rates for older workers appear to have improved. And the earnings loss associated with the displacement of older workers has not changed significantly. Two other significant findings relate to tenure and education. First, the historical protection that older workers appeared to have against displacement was due to tenure not to age per se. Controlling for tenure, the probability of displacement increases with age. Second, college education is no longer a source of significant protection in the world of displacement, and its importance has declined sharply for re-employment.
\end{abstract}


The employment of older workers into their mid-60s will be critical to their ability to ensure a secure retirement. Continued employment provides current income while working, avoids the actuarial reduction in Social Security benefits, allows 401(k) accumulations to increase, and shortens the period over which retirement assets must provide support. One of the risks threatening the ability to work to older ages is being "displaced," with displacement defined as the elimination of the worker's job due to a shift in the demand for labor. Displacement can easily throw 50-year-old workers off course, disrupt their retirement saving plans, and lead to premature retirement.

This paper explores the relationship between job loss and age over the period 1984-2004 using the biennial Displaced Worker Supplement to the Current Population Survey. Several factors have changed over this period that would be expected to affect this relationship. First, the educational attainment of older workers has improved significantly. As education has been shown to be a protection against displacement, this could be expected to reduce the likelihood of displacement of older workers. Second, the pension environment has moved from a defined benefit to a defined contribution world. As the cost of defined benefit pensions rises rapidly as workers age, the shift to defined contribution plans would reduce the relative cost of older workers and therefore make them more desirable. On the other hand, the pension shift also signals a breakdown in traditional lifetime employment relationships suggesting more displacement among older workers. This shift has been accompanied by a noticeable decline in job tenure for older workers.

This paper analyzes the effect of such changes on the displacement of older workers and the effects of such displacement. The first section summarizes what is known about displacement from earlier studies. The second section describes the changing characteristics of workers and the labor market. The third section presents basic displacement data for the past two decades. The fourth section reports the results of regression analysis aimed at isolating the impact of tenure, education, pension coverage, and other variables on the probability of displacement, re-employment, and the magnitude of wage loss. In the case of tenure, researchers have shown that job tenure affects re-employment probabilities and the change in wages suffered by displaced workers, but they had not, to date, explored the impact on displacement probabilities as 
the data for such analysis have been available only in the last few years. The fifth section turns to the Health and Retirement Study and reports regression results for the probability of displacement and the long-term effect of displacement on the probability of work. The sixth section concludes.

The bottom line is good news and bad news. The good news is that the Displaced Worker Surveys reveal no trend toward increasing displacement or worsening outcomes for older workers. The bad news is that earlier results showing lower probabilities of displacement for older workers were based on the correlation between tenure and age. Controlling for tenure, age does not protect workers from being displaced.

\section{What We Know about Displacement and Displacement Outcomes}

Workers who are permanently and involuntarily separated from their jobs, for reasons unrelated to their own performance, are categorized as displaced workers. The phenomenon is significant. For example, during the period 2001-2003, about 11 million workers were displaced. ${ }^{1}$ Displaced workers suffer an immediate loss of earnings, a period of unemployment, and generally a significant decline in earnings when reemployed. ${ }^{2}$

Previous research suggests that the experience of older workers differs from that of the rest of the workforce in two important ways. First, older workers have had lower displacement rates than younger workers. ${ }^{3}$ The conventional explanation is that they have more firm-specific human capital (Becker 1975). Employers and workers share the costs of workers acquiring firm-specific human capital when workers are young. When workers age the employer enjoys the fruits of this investment because workers are more productive, and workers gain as their wages, defined benefit pension accruals, and other

\footnotetext{
${ }^{1}$ http://www.bls.gov/news.release/disp.nr0.htm

${ }^{2}$ For a summary of the literature on displaced workers to 1998, see Kletzer (1998). Using the Panel Study of Income Dynamics, Polsky (1999) found that the consequences of job loss worsened between the periods 1976-81 and 1986-91.

${ }^{3}$ Farber (1993, 1997, 1997, 2003, and 2005), using the Displaced Worker Surveys (DWSs), showed that the probability of displacement declines with age when looking at men and women together. Boisjoly, Duncan, and Smeeding (1998), using the Panel Study of Income Dynamics, found that the likelihood of involuntary joblessness for men with the same level of education is higher among younger men than among those over 50. Rodriguez and Zavodny (2000 and 2003) using the DWSs from 1984-1998 show that the probability of displacement decreases with age.
} 
forms of compensation rise with tenure at the firm. ${ }^{4}$ Employers are reluctant to lay off older workers because they would lose their investment and be forced to train new younger workers. Virtually every study looking at displacement rates has concluded that the probability of being displaced declines with age.

On the other hand, the same firm-specific capital that protects workers from being displaced also means that they suffer particularly large losses when they are displaced. ${ }^{5}$ Because their firm-specific skills, which justified higher wages at their old employer, are not valued by other employers, they experience significant declines in earnings when they find re-employment. ${ }^{6}$ For the same reason, older workers also tend to take a longer time to find new employment, and many in their late 50s and early 60s simply opt for retirement. $^{7}$

\section{Changes That Could Affect Displacement}

The question addressed in this paper is whether the risk of displacement and displacement outcomes for older workers has changed over time. Several factors would lead one to think that the situation has improved and some that it has worsened.

Greater Educational Attainment. Over the 1984-2004 period, the educational attainment of older workers (55-64) improved dramatically. The percentage of those 5564 with a bachelor's degree or higher doubled from 14 percent to 28 percent (see Table 1). Education increases generic human capital and makes workers more flexible, which should make them more attractive to employers. Perhaps more importantly, the discrepancy between the educational attainment of older and younger cohorts has almost

\footnotetext{
${ }^{4}$ Abraham and Farber (1987) and Altonji and Shakotko (1987) demonstrated a positive relationship between tenure and earnings, supposedly reflecting the acquisition of firm-specific skills. Topel (1991) challenged these results, arguing that it was unclear whether the relationship reflected the acquisition of firm-specific skills or simply that high-wage jobs survive or that more productive people change jobs less frequently, both of which would produce a positive relationship between tenure and wages. Correcting for these possible biases and using the first 16 waves of the PSID, Topel estimated that 10 years of seniority raises the wages of the typical male worker by 25 percent over what he could earn elsewhere.

${ }^{5}$ Valletta (1991) found that men with the highest tenure (15 years or more) are among those most affected by displacement, with an increased duration of joblessness.

${ }^{6}$ According to Farber (1997, 2003, and 2005) using the DWSs from 1984-1996 and Rodriquez and Zavodny (2000 and 2003) using the DWSs from 1984-1998, the difference between pre-displacement and post-displacement wages increases directly with age.

${ }^{7}$ Farber (1997, 2003, and 2005) reports that displaced workers aged 45-64 are less likely to find a new job within a few years than younger workers.
} 
completely disappeared. In 1984 the percentage of the 25-34 population with a bachelor's degree or higher was 10 percentage points higher than those 55-64 (24 percent versus 14 percent). By 2004, this gap had narrowed to 2 percentage points (30 percent versus 28 percent). In short, older workers now look very much like younger workers in their educational attainment. Moreover, the entire population has become familiar with computers, and recent studies show that the use of computers among workers 50 and over has doubled since the mid 1980s. ${ }^{8}$

Technical Change, Globalization, and a Shift from Goods to Services. The employment systems within firms have also changed in ways that potentially create more dislocation, but also more reemployment opportunities for older workers. Changes in goods markets and the production process, and the employment shift from goods producing to service producing industries, have led employers to move away from the hierarchical structures and career employment that protected older workers, but that Hutchens (1988 and 1993) found so inimical to older job seekers. The percent of workers involved in the production of goods has declined from 35 percent in 1984 to 24 percent in 2004 (see Figure 1). More generally, employers have adopted new technologies and project structures that place far less weight on firm-specific human capital and seniority within the organization. ${ }^{9}$

Shift from Defined Benefit to Defined Contribution Plans. The shift in the production and employment systems has been accompanied by a major shift in the nature of pension coverage. In the early 1980s, roughly 60 percent of those with private pension coverage were covered by a defined benefit plan only, 20 percent by a defined contribution plan only, and 20 percent by both (see Figure 2). In 2004, the percentages had reversed so that 60 percent were covered by a defined contribution plan only, with the remainder divided equally between defined benefit plan only and both. Because the cost of defined contribution pensions is not age related, older workers with the appropriate skills are not priced out of the market by new hires. On the other hand, the demise of defined benefit plans also signals the end of long-term employment

\footnotetext{
${ }^{8}$ See, for example, Friedberg (2001).

${ }^{9}$ See Aaronson and Housinger (1999) and Addison, Fox, and Ruhm (1996) for a discussion of the impact of technology on displacement.
} 
commitments and the ability to get rid of older workers through incentives in the plan rather than layoff.

Aging of Baby Boom. The baby boomers have become an increasing proportion of the workforce. In 1984, those 55-64 accounted for 10 percent of the workforce; today that percentage has increased to 12 . And this percentage will continue to rise as the baby boom ages. The lead edge of the baby boom is currently 60 . The question is whether the large number of aging boomers gives employers the sense that they are overloaded with older workers, leading to a desire to "rebalance" the age structure of their workforce. ${ }^{10}$ Tenure. Although many commentators cite the increased mobility of the U.S. workforce as a major reason for the spread of 401(k) plans, whether mobility has in fact increased over time is an unsettled and controversial question. Most statistics look remarkably stable. The median tenure with current employers for workers 25 and older has hovered around 5 years for the last two decades. Similarly, among those 45-49, about 45 percent have been with their employer for more than 10 years. ${ }^{11}$ Determining trends in labor mobility, however, involves sorting out cyclical factors and changes in the age and sex composition of the labor force. ${ }^{12}$ Economists who have studied trends in mobility have split into two camps - one that supports the popular view of increased mobility, and another camp that disputes it. ${ }^{13}$

\footnotetext{
${ }^{10}$ Over time, employers can be expected to adjust their compensation systems to reflect this shift in the relative supply of workers of different ages. The decision of many employers to freeze their defined benefit pension plans or shift to cash-balance formats, both of which specifically reduce the compensation of older workers, could reflect such adjustments. See Munnell, Golub-Sass, Soto, and Vitagliano (2006).

${ }^{11}$ In both cases this consistent pattern over time is the result of increasing tenure for men and decreasing tenure for women.

${ }^{12}$ For example, greater participation by women pushes average job tenure lower, as women enter and exit the labor force to raise children. But as more women build careers, tenures increase. The age distribution of the labor force is also important, since older workers are more likely to be in longertenure jobs.

${ }^{13}$ Using the CPS data mentioned above, the first group of researchers finds a moderate decline in job stability overall from the 1980s into the early 1990s, though women experienced increased stability (Neumark, Polsky, and Hansen (1999)). This group also detects a decline in job stability for older workers, especially men, which points to a decline in career jobs. Jaeger and Stevens (1999), using data from the PSID, finds a decline in the share of workers with 10 or more years of tenure with the same employer. With most of the change occurring among older workers towards the end of the period, their results are consistent with popular opinion. Aaronson and Sullivan (1999), using CPS data, find displacement rising among high-tenure workers between 1979 and 1995. The skeptics employ different data sets and different measures to challenge the conventional wisdom. Using the PSID and monthly data from the Survey of Income and Program Participation, Gottschalk and Moffitt (1999) find no change in short-term turnover for male workers between the 1980s and 1990s. Using the March CPS (a more extensive survey than the standard CPS used in the studies mentioned above),
} 
For older workers, however, it seems clear that tenure has declined over the last two decades. Data from the Mobility Supplement of the Current Population Survey shows that median tenure of workers age 55-64 has fallen from a high of 13 years in 1983 to 10 years in $2004 .{ }^{14}$ And the percentage of workers with 10, 15, and 20 years on the job has fallen sharply. In the early eighties, 35 percent of workers age 55-64 had 20 or more years of tenure; in 2004 that figure had declined to 29 percent. Similar declines were evident for those with 10 years and 15 years (see Figure 3 ).

\section{The Displaced Worker Surveys}

The data reported below come from the 1984-2004 Displaced Workers Surveys (DWSs), which were conducted as part of the January Current Population Survey (CPS) in 1984, 1986, 1988, 1992, 2002, and 2004 and the February CPS in 1994, 1996, 1998, and 2000. The survey attempts to measure the incidence of job loss due to a shift in labor demand by asking workers whether they have been displaced for one of the following reasons:

1. their plant or company closed down or moved;

2. their company had insufficient work;

3. their position or shift was abolished;

4. a seasonal job was completed;

5. a self-operated business failed;

6. other reason.

Those who respond affirmatively are included in the DWS. These data do not include all job loss within the economy. First, the DWS collects and reports information on only one job loss for each individual. Since a number of workers lose more than one job during the sample period, the DWS underestimates the total amount of job loss. Second, the distinction between layoffs and quits is not always clear. For example, firms

Stewart (2002) finds that the rate at which employees separated from their jobs actually decreased slightly between 1976 and 2000. Farber (1997) finds that long-term employment remains common in the United States, though the distribution of those jobs appears to be changing as women compete with men for the long-term jobs.

${ }^{14}$ Moreover the decline in tenure for the workers as a group reflected no change in the median tenure of 10 years for women over the 1983-2004 period and a decline in tenure for men of 16 to 11 years. 
may attempt to reduce the workforce by cutting or not raising wages, thus encouraging workers to quit.

In addition, the changing characteristics of the surveys require some adjustments to the data. First, the 1984-1992 surveys asked whether individuals were displaced during the previous five years, whereas the 1994-2004 surveys asked about displacement during the previous three years. For consistency, this analysis follows the method developed by Farber (1997) and focuses on workers who were displaced during the last three years. $^{15}$ Second, while surveys before 1992 asked workers in all displacement categories follow-up questions, such as what year they lost their job or their earnings on their last job, the 1994-2004 surveys followed up only with workers displaced for the first three reasons described above. Therefore, for all years, the numbers reported below include only workers in the first three categories.

Figure 4 shows that the first three categories - plant closing, insufficient work, and shift abolished - account for the bulk of displacement. Reasons (4) seasonal job completed and (5) self-operated business failed have constituted only a tiny portion of the total throughout the period. Reason (6) "other" requires a little explanation. In early work, Farber (1997) reported a sharp increase in displacement due primarily to a growth in the "other" category. Caution offered by other researchers and an analysis of debriefing questions for the outgoing sample of the 1996, 1998, and 2000 DWSs convinced Farber (2003) that only a minority of job loss for 'other' reasons was truly involuntary. ${ }^{16}$ As a result, he included only about 25 percent of "other" job loss for DWSs in 1994 and later and, based more on an assumption than evidence, 62 percent for the 1992 and earlier surveys. Figure 4 incorporates these adjustments. While focusing on the first three categories excludes some involuntary job loss, it provides a more consistent series for the period under review.

\footnotetext{
${ }^{15}$ To avoid comparing three-year displacement rates with five-year displacement rates, it is necessary to count only job loss in the most recent three years for the 1984-1992 surveys. But this approach alone would underestimate job loss in the most recent three years, because some fraction of the workers who lost their job in years four and five lost a shorter job in the most recent three-year period. Using data from the PSID, Farber (1997) estimates that about 30 percent of workers who lost their jobs four years earlier lost another job in the next three years and 27 percent of workers who lost a job five years earlier lost another job in the three years immediately preceding the survey. These numbers suggest an upward adjustment of about 11 percent to the three-year job loss rates in the 1984-1992 DWSs. This adjustment is reflected in Figure 4.

${ }^{16}$ Abraham (1997).
} 
Figure 5 shows displaced workers aged 50-64 as a percent of total displaced workers for three surveys - 1984, 1994, and 2004. Older workers are clearly accounting for an increasing portion of those displaced. Figure 6 suggests, however, that this increase reflects the growing share of older workers in the labor force rather than an increase in the displacement rate for older workers. To see whether this assumption is correct, the next step is to look at displacement rates and displacement outcomes by age.

The following tables report displacement rates, re-employment rates, and real earnings change by age for the 1984-2004 surveys. ${ }^{17}$ The columns are identified by the year of the survey - for example 2004 - but the survey refers to workers who were displaced in the previous three years - 2001-2003. Following Farber, the displacement rate is the number of reported job losers over the three year period - 2001, 2002, and 2003 - divided by the number of workers employed in the survey date, in this case 2004, plus those who had reported a job loss in the 2001-2003 period but who were not employed in 2004.

Three conclusions emerge from Table 2. First, displacement rates, which range from 12.7 percent in the 1984 survey to 6.3 percent in 2000 , are cyclical. This pattern is evident in Figure 7, which plots the average displacement rate for each DWS against three-year averages of the civilian unemployment rate. Second, displacement rates tend to decline with age at least up to age 55. Third, no discernable upward or downward trends are evident over the 20-year period.

Table 3 presents the post-displacement re-employment rates by age. The overall re-employment rates, which range from a low of 62.5 percent for the 1984 survey to a high of 76.3 percent for the 1998 survey, also vary with the business cycle. Second, the re-hire prospects tend to increase until age 40-44 and then decline steadily for workers in older age groups. Third, the re-employment prospects for older workers appear to have increased somewhat over time relative to the experience of younger workers.

Table 4 shows the average percent change in real wages for those displaced workers who were re-employed by the survey year. Displaced workers age 30 and over have consistently seen a decline in their real wages as they move from their old to their

\footnotetext{
17 These tables follow the format presented in Rodriguez and Zavodny (2000).
} 
new jobs. ${ }^{18}$ For all displaced workers, this decline shows a cyclical pattern, ranging between a 2-percent decline during boom years as shown in the 2000 survey to a 21percent decline during the recent slowdown reflected in the 2004 DWS. Wage losses tend to increase with age over the entire period, with those 50 and over losing about a third of their real wage as a result of displacement. Since the DWSs do not provide information on hourly wages, total wage loss can reflect both a decline in the hourly wage and a reduction in hours worked. ${ }^{19}$

The conclusion that emerges from the basic data is that the probability of being displaced and re-employed has not changed very much over the last twenty years for workers as a whole. Wage loss patterns also do not appear to have changed over time. As others have documented, older workers appear to have a lower probability of being displaced than younger workers, but a harder time getting rehired and, if rehired, suffer more of a decline in real weekly earnings than their younger counterparts. The more recent surveys suggest that re-employment prospects may have improved somewhat for older workers relative to younger ones. The question is what role job tenure, education, and other factors play in these patterns. To explore this question, the following section reports on regression equations that relate the probability of displacement and displacement outcomes to job tenure and other variables.

\section{Regression Results of Displacement and Displacement Outcomes}

The following tables report regression results for three phenomena; the probability of being displaced, the probability of being re-employed once displaced, and

\footnotetext{
${ }^{18}$ The decline in earnings between the lost job and the job held at the DWS survey date understates the loss in earnings. If the displaced worker had not lost his or her job, earnings would likely have grown over the interval between the date of job loss and the DWS survey date. See Jacobson, Lalonde, and Sullivan (1993). Farber (2005) measures this earnings growth by examining the earnings of non-displaced workers using data from the CPS outgoing rotation groups. Farber's results show that full-time workers who find a new job earn about 13 percent less on average at their new jobs than on their lost jobs. Counting foregone earnings increases enjoyed by non-losers raises the total loss for full-time workers to 17 percent.

${ }^{19}$ As one approach to sorting out the effect of lower hourly wages versus fewer hours, Farber (1997) focused on the sub-sample of workers who were displaced from and moved to full-time jobs. This comparison produced smaller earnings losses than for the group as a whole, but they were still sizable. Stevens (1997) using the PSID found that annual earnings declined because of both a fall in wages and a decline in hours.
} 
the percentage difference between pre- and post-displacement wages. These regressions serve three purposes: to update and confirm the results of earlier researchers; to identify trends in the displacement and displacement outcomes for older workers, and to highlight the effect of tenure, education, and various other factors on each outcome.

\section{The Probability of Displacement}

A probit regression is used to estimate the probability of being displaced because of plant closure, position abolished, or slack work. The dependent variable is equal to one if the worker was displaced during the three-year survey period and zero otherwise. A separate equation, excluding the tenure variable, is estimated for each displaced worker survey. An additional set of equations is estimated for the 1996 and later surveys when tenure information became available for all CPS respondents.

The full regression results are presented in Appendix Table A1. These equations include variables used in earlier studies - gender, marital status, non-white, education, industry, and full-time status - to confirm the traditional findings. ${ }^{20}$ The coefficients of the age variables are shown in Table 5. The coefficients that are statistically significant at the 95 percent level are starred. The omitted age group is 20-24. As in earlier studies, the probability of being displaced declines with age. For example, the probability of being displaced for workers aged 50-64 appears to be 1-4 percentage points less than for workers age 20-24. Although the coefficients of all the age variables in 2004 are positive and statistically significant, suggesting a greater probability of displacement relative to the omitted group, older workers in their fifties appear to have a lower probability of being displaced than those age 25-49. Thus, this first set of results says that age protects workers from being displaced but suggests that the protection offered by age has declined over time.

Table 6 reports the results for the same equations, except this time tenure variables are included. Tenure information is available for the entire workforce only for the 1996 and later surveys. The results show that tenure - not age - protected older workers from displacement. Holding tenure constant, older workers are actually more

\footnotetext{
${ }^{20}$ Using a more detailed set of 56 industry dummy variables instead of the set of private goods sector, private service sector, and public sector dummy variables had little effect on the coefficient estimates and standard errors for all other explanatory variables in the regressions.
} 
likely than their younger counterparts to be displaced. Figure 9 shows the marginal reduction in the probability of being displaced as tenure increases. ${ }^{21}$ Thus, to the extent that workers change jobs late in their careers, they are increasing their risk of displacement. These older workers lose the protection afforded by tenure and face the increased risk of displacement associated with age.

As in earlier studies, women, married people, and those working full time have a low probability of being displaced, and race appears to have no impact. Private sector workers in goods-producing industries have a higher probability of being displaced than those in private sector service industries. ${ }^{22}$ In contrast, public sector employees have a much lower likelihood of being displaced than their private sector counterparts.

The results for education appear new and interesting. ${ }^{23}$ Initially, having some college and completing college dramatically reduced the probability of being displaced. For example, in 1984, college reduced the probability of displacement by 5 percentage points; by 2002 and 2004 the impact was no longer statistically significant (see Figure 8). In other words, a college education used to protect a worker against displacement; today it has virtually no effect. ${ }^{24}$

Appendix Table A1 also reports probit results that include pension coverage.

Since the January or February CPSs, which contain the displacement and tenure information, do not include any pension variables, it was necessary to impute pension coverage. This involved estimating the probability of having a pension from the March CPSs, including as explanatory variables gender, marital status, nonwhite, education, full-time status, and 56 industry variables, and then using these equations to impute pension coverage to workers in the January or February CPSs. ${ }^{25}$

\footnotetext{
${ }^{21}$ Over the 1996-2004 DWSs, displacement rates averaged 15.9 percent for those with $0-1$ years of tenure; 11.3 percent with $1-5$ years; 5.5 percent with 5-10 years; and 4.0 percent for those with 10 or more years.

${ }^{22}$ Goods producing industries include agriculture, mining, construction and manufacturing. Serviceproducing industries include wholesale and retail trade, finance, insurance and real estate, transportation, communications and public utilities. The private sector goods-producing variable is entered as the interaction between non-public sector and goods industry.

${ }^{23}$ Rodriguez and Zavodny (2003), comparing results for the 1986 and 1988 DWSs with those from the 1996 and 1998 DWSs, noted a decline in the coefficient on the education variable between the two samples.

${ }^{24}$ The historical results showing education providing strong protection against displacement could also be largely spurious, and could in fact be much diminished, or even disappear, if we could control for tenure.

${ }^{25}$ Another approach tried was constructing a measure of pension coverage by industry group, using the Form 5500 from the Department of Labor. This form contains annual data on active participants by type of
} 
Adding pension coverage does not change the story with regard to age variables or any other variable in the equations. ${ }^{26}$ But the coefficients of the pension variables are somewhat puzzling. The thought going into the exercise was that pension coverage, and the interest it implied in employees, probably reduced the likelihood of displacement. This assumption seemed particularly likely in the case of defined benefit plans where workers were often represented by a union that might resist plant closings and other layoffs. Furthermore, defined benefit plans often contain early retirement incentives that would obviate the need to lay off older workers. Instead of a negative effect on displacement, however, the results show that pension coverage increases the probability of being displaced by about 2 percentage points in every survey year. One possible explanation is that workers are only displaced from "good jobs" - that is, jobs with pensions; other workers engage in a spot job market where the concept of displacement is less relevant. The problem, as discussed later, is that pensions have a negative effect on displacement probabilities in equations estimated using the Health and Retirement Study.

The strong conclusion that emerges from the displacement regressions is that controlling for tenure the probability of displacement increases with age. Introducing pension coverage produces difficult-to-explain coefficients, but does not change the basic result.

The Probability of Re-employment

The second set of equations takes those who have been displaced and estimates their probability of being re-employed. As before, the equations include indicator

pension coverage for each private sector company with a qualified plan. If the approach had produced useful results, it would have been possible to sort out effects by type of pension coverage. The exercise involved finding the number of workers in, say, insurance companies covered by a defined benefit plan only, a defined contribution plan only, and both as reported in the Form 5500, and dividing these numbers by the total employees in the insurance industry as reported in the CPS. The next step was to apply these percentages to all those currently employed in the insurance industry or to those whose last job was in the insurance industry. This process produces industry pension coverage for 56 categories that remain consistent between the two datasets and over time in each dataset. To be clear, workers were assigned pension coverage that reflected the percent of workers in their industry covered by a pension. Using this measure, pension coverage also increased the probability of being displaced.

${ }^{26}$ Theoretically, including this imputed variable in the displacement equation could cause incorrect standard errors for the estimations. In this case, including the imputed pension dummy variable had little effect on the coefficient estimates and standard errors for all other explanatory variables. 
variables for educational attainment, gender, marital status, non-white, full-time status, and industry. The re-employment equation also controls for the reason for displacement, since a plant closing or slack work may reflect an industry-wide problem making it more difficult for the displaced worker to find work. The year in which the worker lost his job during the three-year period is also included, since the more distant the job loss the more time the worker has had to find a new job.

Table 7 presents the effects of age on the percent probability of being reemployed. The coefficients suggest that the disadvantage of age with respect to re-employment has declined over time. For example, until 1996 the coefficients for ages 50-54, 55-59, and 60-64 were both large and generally statistically significant. Since 1996, displaced workers 50-54 are generally no less likely to be reemployed than younger workers. And by 2004 , the same was true for those aged 55-59. Only displaced workers in their 60s were at a statistically significant disadvantage. The improved ability of displaced older workers to find a job may well reflect the shift from defined benefit plans, where costs rise sharply with age, to defined contribution plans.

The regression results (see Appendix Table A2) also showed that women and nonwhites continue to be at a severe disadvantage. Even as recently as 2004, nonwhites were 13 percent less likely than whites to be re-employed by the survey year and women 7 percent less likely than men. One year of additional tenure on the job from which the worker is displaced reduces the probability of re-employment by about 0.3 percentage points. The suggestion is that the firm-specific skills and wages that increase with tenure make it more difficult for the worker to find comparable employment. Re-employment probabilities increase with education, but the advantage of having completed college fell by more than half over the 1984-2004 period. $^{27}$ Having been employed full time increases the probability of re-employment, although the coefficient varies a lot over time, suggesting an advantage of 1- to 8 percentage points over those displaced from a part-time job. Re-employment also increases with time elapsed since displacement. In terms of reason for displacement, slack work had a statistically significant negative effect compared to position abolished on the probability of re-employment through 1996,

\footnotetext{
${ }^{27}$ The variables associated with an increased probability of employment are also those generally associated with positive coefficients in earnings equations. This suggests the existence of a labor supply effect-those with higher education have stronger incentives to remain in the labor force for example.
} 
insignificant thereafter. ${ }^{28}$ Business closing no longer appears to have a statistically significant effect on the probability of re-employment.

\section{The Change in Wages Due to Displacement}

The third equation explores the factors that affect the percent change in wages from displaced workers' old jobs to their new ones. In order to isolate the effect on earnings from a decline in hourly wages, as opposed to a reduction in weekly hours, the equation includes a sub-sample of workers who were displaced from and moved to fulltime jobs. The results for the age variables are shown in Table 8. Prior to the 1998 survey, earnings losses increased with age, after which the effect of age on earnings loss virtually disappears. The exception is 2004 , where age groups, 40-44, 45-49, and 50-54 have a large negative and statistically significant effect on earnings. Thus, it would be hard to argue that older displaced workers who find new jobs are experiencing larger earnings effects relative to younger workers in 2004 than they did in 1984.

In terms of the other variables in the equations (shown in Appendix Table A3) only tenure on the old job has a consistent statistically significant effect over time. The equations show that each year of job tenure in the old job is associated with additional reemployment wage loss of 1-2 percent.

\section{Summary}

The regression results from the DWSs with regard to older workers show the following. First, holding tenure constant, older workers are more likely to be displaced than their younger counterparts. The protection associated with age per se probably never existed, but rather reflected the fact that older people had greater tenure. Moreover, the protective effect of education has declined sharply over time. Second, those 55-59 and 60-64 are about 20 percent less likely to be re-employed than younger workers, although those aged 55-59 appeared to suffer no disadvantage in the 2004

\footnotetext{
${ }^{28}$ This result is consistent with the argument put forth by Gibbons and Katz (1991) that when firms have discretion about whom to layoff, they lay off the least productive workers. Abolishing a position suggests less flexibility on the employer's part than insufficient work, and therefore someone laid off because of insufficient work would be expected to have a more difficult time gaining reemployment. Although Gibbons and Katz found evidence to support their hypothesis, the equations estimated in this study did not produce any systematic relationship between the reason for displacement and the ability of workers to find new employment or, if rehired, minimize wage loss.
} 
survey. Finally, with the exception of 2004, wage loss has not been related to age since 1996. Tenure has a statistically significant negative effect on wage change. Both displacement and displacement outcomes were highly cyclical, but they displayed no secular trends over time with the exception of a slight improvement in the re-employment probabilities of workers in their fifties.

\section{Results from the HRS}

This section estimates the probability of displacement using the Health and Retirement Study (HRS) - instead of the DSW - to determine whether age, tenure, and the other variables used in the DWS equations have the same effect. The HRS is a nationally-representative data set that began in $1992 .^{29}$ This original survey interviewed people age 51-61 and their spouses (regardless of age), with about 12,650 individuals from about 7,600 households. Children of the depression (1923-1930) and War Babies (1942-1947) were added in 1998, bringing the total sample to more than 22,000. The survey was re-administered in 1994, 1996, 1998, 2000, 2002, and 2004. The HRS contains detailed information on education, job history, health, and many other demographic and economic variables and therefore is ideal for this study. ${ }^{30}$

Table 9 presents the results of three equations that estimate the probability of being displaced. In each case, the sample consists of those who were working in a previous period. The equations examine whether the individual reported displacement (not working because of business closed or laid-off) between the wave in which the individual last worked and the following wave in which the individual is observed. All the equations include three age groups 50-54, 55-59, and 60-65; under 50 is the omitted group. In addition, the equations include variables used in the DWS regressions gender, marital status, nonwhite, education, tenure, and industry as well as establishment size which is not included in the DWS regressions.

The first equation, which includes tenure, supports the finding from the DWS that age does not protect workers from displacement. As in the earlier DWS equations, it is

\footnotetext{
${ }^{29}$ The HRS is conducted by the Institute for Social Research (ISR) at the University of Michigan and is made possible by funding from the National Institute on Aging. More information is available at the ISR website: http://hrsonline.isr.umich.edu/.

${ }^{30}$ See Juster and Suzman (1995) for a detailed overview of the survey.
} 
tenure that has a large and statistically significant effect. Tenure of ten or more years reduces the probability of displacement by 11 percentage points compared to tenure of less than one year. Even 5-9 years of tenure reduces the displacement probability by 5 percentage points. These magnitudes are roughly the same as those found in the analysis of the DWS data.

Many of the other variables in the equation also have results consistent with the DWS regressions. Being female or married reduces the likelihood of being displaced. Having a college education reduces the probability of displacement by a small amount 1 percentage point - which is also consistent with the DWS results. Being nonwhite appears to have no effect on the probability of displacement for the HRS population, whereas it alternates between no effect and a slightly positive effect on displacement in the DWS regressions.

The HRS also has extensive information on pension coverage for each individual, making it possible to test the impact of pensions on the probability of displacement. (As discussed earlier, the January and February CPSs which form the basis for the DWS analysis do not have pension data, so pension coverage had to be imputed from information in the March CPS.) The second HRS equation introduces a dummy variable for pension coverage. The variable equals one if the person has pension coverage in his current job. For those who had been displaced, pension coverage is determined at the job where the displacement occurred. Pension coverage has a statistically significant effect and reduces the probability of being displaced by about one percentage point. Including pension coverage has virtually no effect on the coefficients of the other variables in the equation with the exception of tenure, where it reduces the effect.

The final equation breaks down pension coverage into "defined benefit only," "defined contribution only," or "both." Only "defined benefit only" or "both" have statistically significant coefficients. The results suggest that coverage under a "defined benefit plan only" reduces the probability of displacement by about 4 percentage points, compared to 2.7 percentage points for "both" and 1.9 percentage points for "defined contribution plan only." The results are consistent with intuition as discussed earlier, but not with the results when the pension coverage proxy was included in the CPS equation. 
In an attempt to reconcile the contradictory results regarding the impact of pensions on the probability of displacement, the HRS equation was re-estimated using imputed pension coverage rather than the pension coverage actually reported by the HRS respondents. That is, each HRS respondent was assigned pension coverage based on the results of a probit equation that related the probability of having a pension to an array of demographic, economic, and industry information. The coefficient estimate on imputed pension was positive but statistically insignificant suggesting that the DWS results are driven by the imputation. ${ }^{31}$ However, including the imputed pension dummy variable had little effect on the coefficient estimates and standard errors for all other explanatory variables in both surveys.

The HRS also allows an estimate of the permanent impact of displacement, which helps to refocus on why displacement is such an important topic. People in the future are going to have to work longer if they are going to have an adequate retirement. Surveys consistently show that people plan to stay in the labor force until age 65 , but the median actual retirement age is 62 (EBRI 1990-2005). Part of the explanation is that people get thrown off course because of some negative shock. A recent study (Johnson, Mermin, and Uccello (2005)) using the HRS found that about 7 in 10 adults who were age 51-61 in 1992 developed health problems, lost their jobs, or lost a spouse due to death and divorce during the 10-year period ending in 2002. One in five lost their job over the 10year period.

Continued employment requires that workers are not thrown off track by losing their jobs in their fifties. Many never recover fully. As the Displaced Worker Surveys show, less than 65 percent of displaced workers in their fifties find a new job by the survey date. And those workers who do find a new job suffer a substantial loss in earnings and pension benefits and forfeit the tenure that protects them from displacement in the future. Thus, displacement seriously reduces the likelihood that older people will be employed and able to save for retirement.

To assess the impact of displacement on employment, the last HRS equation takes advantage of questions in the HRS about whether the person had been displaced or laid

\footnotetext{
31 This suggests an endogeneity problem whereby unobservable worker characteristics are positively associated with pension coverage and negatively associated with displacement.
} 
off to estimate the impact of these events on future employment. The sample consists of those who are working when they first enter the sample, so that the population under consideration represents people with an attachment to the labor force. In the estimated equation, the dependent variable is one if the person who was working when first observed is currently working, and zero otherwise. The results show that, controlling for age, education, being female, married, nonwhite, and survey year, having been laid off reduces the probability of working in subsequent waves by 11 percentage points and being displaced reduces the probability by 21 percentage points. ${ }^{32}$ Thus, being forced to leave a job has a lasting effect on the employment prospects of older people. But that effect appears to decline somewhat over time, since the coefficient on the variable representing years since displacement shows that each year reduces the probability of displacement by about one percentage point.

\section{Conclusion}

People will have to work longer in the future, because Social Security will replace a smaller share of pre-retirement earnings and 401(k) balances are unlikely to provide adequate retirement income. People often plan to work to 65, but get thrown off track by a negative shock. One major shock is job loss, which happens to one in five people in their fifties. Job loss not only causes an immediate loss of earnings, but has lasting adverse effects. The question addressed in this paper is whether job loss due to displacement is becoming more or less of a problem for older workers.

Several developments would lead one to think that older workers would be less likely to be displaced today than they were in the past. They are better educated, and the gap in educational attainment between older workers and their younger counterparts has virtually disappeared. Older workers are healthier today than they have been in the past. Also, goods-producing industries, which have been under enormous global competition and where layoffs are more prevalent, are becoming a less important component of the American economy. The shift from defined benefit to 401(k) plans might be thought to

\footnotetext{
${ }^{32}$ This result is broadly consistent with Chan and Stevens (2001) who use the HRS to estimate hazard models for returning to work and for exiting post-displacement employment for ten years following a job loss. The authors concluded that job loss has a large and lasting effect. Four years after a job loss, for those age 55, the employment rate of displaced workers is 20 percentage points below that of non-displaced workers.
} 
increase displacement, since employers can no longer rely on the early retirement incentives in defined benefit plans to reduce their workforce. Re-employment should be easier, however, given that the costs of 401(k) plans are not age related. The aging of the baby boom might give employers the sense they are overloaded with older workers and an incentive to rebalance their labor force portfolio. Finally, older workers today end up with less job tenure than their counterparts 20 years ago, and this reduction in tenure might make them more vulnerable.

The major findings of this study are as follows. No major trends in the displacement of older workers have occurred over the 11 Displaced Worker Surveys conducted during the 1984-2004 period. Re-employment rates for older workers appear to have improved, perhaps because of the move away from defined benefit plans and all they imply in terms of costs, hierarchical structures, and career employment. The earnings loss associated with the displacement of older workers has not changed significantly. In short, things are not getting worse, and maybe even a little better

The other really interesting findings relate to tenure and education. First, the historical protection that older workers appeared to have against displacement was due to tenure not to age per se. Controlling for tenure, the probability of displacement increases with age. This finding means that older workers who lose their jobs are particularly vulnerable. Second, college education is no longer a source of significant protection in the world of displacement, and its importance has declined sharply for re-employment. Thus, while older workers are significantly more educated than in the past, this improvement most likely has no effect on the probability of displacement.

The conclusion that displacement is not getting worse is not to say that it is not a significant problem for workers in their fifties and early sixties. If people are going to have to keep working on a full-time basis until age 65 to have a secure retirement income, it may make sense to develop more of a support network to help workers rebound from such a severe shock to their work and economic life. 


\section{REFERENCES}

Aaronson, Daniel, and Kenneth Housinger. 1999. "The Impact of Technology on Displacement and Reemployment." Federal Reserve Bank of Chicago Economic Perspectives 23 (Second Quarter): 14-30.

Aaronson, Daniel and Daniel G. Sullivan. 1998. "The Decline of Job Security in the 1990s: Displacement, Anxiety, and Their Effect on Wage Growth." Federal Reserve Bank of Chicago Economic Perspectives 22 (First Quarter): 17-43.

Abraham, Katherine. 1997. "Comment On 'The Changing Face of Job Loss in the United States, 1981-1995."'Brookings Papers on Economic Activity: Microeconomics, $135-42$.

Abraham, Katherine G. and Henry S. Farber. 1987. "Job Duration, Seniority, and Earnings.” American Economic Review. 77:3, 278-297.

Addison, John T., Douglas A. Fox, and Christopher J. Ruhm. 1996. "Trade Sensitivity, Technology, and Labor Displacement.” National Bureau of Economic Research Working Paper 5621, June.

Altonji, Joseph, and Robert Shakotko. 1987. "Do Wages Rise with Job Seniority?" Review of Economic Studies. 54:4, 437-459.

Becker, Gary. 1975. Human Capital. New York: Columbia University Press.

Boisjoly, Johanne, Greg J. Duncan, and Timothy Smeeding. 1998. "The Shifting Incidence of Involuntary Job Losses from 1968 to 1992.” Industrial Relations 37 (April): 207-31.

Chan, Sewin and Ann Huff Stevens. 2001. "Job Loss and Employment Patterns of Older Workers." Journal of Labor Economics. Vol 19, no. 21 pp 484-521.

Chan, Sewin and Ann Huff Stevens. 2002. "How Does Job Loss Affect the Timing of Retirement?" National Bureau of Economic Research Working Paper 8780, February.

Diebold, Francis X., David Neumark, and Daniel Polsky. 1997. "Job Stability in the United States." Journal of Labor Economics 15 (April): 206-33.

EBRI. 1990-2005. Retirement Confidence Surveys.

Farber, Henry S. 1993. "The Incidence and Costs of Job Loss: 1982-91.” Brookings Papers on Economic Activity: Microeconomics, No. 1:73-119. 
_ 1997. "The Changing Face of Job Loss in the United States, 1981-1995." Brookings Papers on Economic Activity: Microeconomics, 55-128.

— 1997. "Trends in Long-Term Employment in the United States, 1979-1996" Working Paper 384, Industrial Relations Section, Princeton University (July).

—. 2003. "Job Loss in the United States, 1981-2001.?" Working Paper 471, Industrial Relations Section, Princeton University (Revised May 22).

- 2005. "What Do We Know about Job Loss in the United States, 1984-2004?" Working Paper 498, Industrial Relations Section, Princeton University (January).

Friedberg, Leora. 2001. "The Impact of Technological Change on Older Workers: Evidence from Data on Computer Use." NBER Working Papers 8297.

Gibbons, Robert, and Lawrence Katz. 1991. "Layoffs and Lemons." The Quarterly Journal of Economics. 102:1, 51-75.

Gottschalk, Peter and Robert Moffitt. 1999. "Changes in Job Instability and Insecurity Using Monthly Survey Data." Journal of Labor Economics 17 (October, Pt. 2): S91-126.

Hipple, Steven. 1999. "Worker Displacement in the Mid-1990s." Monthly Labor Review 122 (July): 15-32.

Hutchens, Robert M. 1988. "Do Job Opportunities Decline with Age?" Industrial and Labor Relations Review 42(1): 89-99.

Hutchens, Robert M. 1993. "Restricted Job Opportunities and the Older Worker." In As the Workforce Ages: Costs, Benefits and Policy Challenges, edited by Olivia Mitchell, 81-102. Ithaca, NY: ILR Press.

Jacobson, Louis S., Robert J. Lalonde, and Daniel G. Sullivan. 1993. "Earnings Losses of Displaced Workers." American Economic Review 83 (September): 685-709.

Jaeger, David A. \& Stevens, Ann Huff. 1999. "Is Job Stability in the United States Falling?," IZA Discussion Papers 35, Institute for the Study of Labor (IZA).

Johnson, Richard W., Gordon B.T. Mermin, and Cori E. Uccello. 2005. "When the Nest Egg Cracks: Financial Consequences of Health Problems, Marital Status Changes, and Job Layoffs at Older Ages." Working Paper \#2005-18. Chestnut Hill, MA: Center for Retirement Research at Boston College.

Juster, F.T. and R. Suzman. 1995. The Health and Retirement Study: An Overview. HRS Working Papers Series \#94-1001; Journal of Human Resources, 1995 Supplement (JHR 30-S). 
Kletzer, Lori G. 1998. “Job Displacement.” Journal of Economic Perspectives 12 (Winter): 115-36.

Munnell, Alicia, Francesca Golub-Sass, Mauricio Soto, and Francis Vitagliano. 2006. "Why Are Healthy Employers Freezing Their Pensions." Issue Brief \#44. Chestnut Hill, MA: Center for Retirement Research at Boston College.

Neumark, David, Daniel Polsky, and Daniel Hansen. 1999. "Has Job Stability Declined Yet? New Evidence for the 1990s." Journal of Labor Economics 17 (October, Pt. 2): S29-64.

Polsky, Daniel. 1999. "Changing Consequences of Job Separation in the United States." Industrial and Labor Relations Review 52 (July): 565-80.

Rodriguez, Daniel and Madeline Zavodny. 2003. "Changes in the Age and Education Profile of Displaced Workers." Industrial and Labor Relations Review. Vol. 56, No. 3 (April): 498-510.

- 2000. “Are Displaced Workers Finished at Forty?” Economic Review. Federal Reserve Bank of Atlanta. Second Quarter: 33-47.

Ruhm, Christopher J. 1991. "Are Workers Permanently Scarred by Job Displacement?" American Economic Review. 81:1. 319-323.

Stevens, Ann Huff. 1997. "Persistent Effects of Job Displacement: The Importance of Multiple Jobs.” Journal of Labor Economics. 15:1, 165-188.

Stewart, J. 2002. "Recent Trends in Job Stability and Job Security: Evidence from the March CPS.” Working Paper 356. U.S. Bureau of Labor Statistics.

Topel, Robert. 1991. "Specific Capital, Mobility, and Wages: Wages Rise with Job Seniority." Journal of Political Economy 99 (February): 145-76.

Valletta, Robert G. 1991. "Job Tenure and Joblessness of Displaced Workers." Journal of Human Resources 26 (Fall): 726-41. 
Table 1. Percentage of Population 25 Years Old and Over with a Bachelor's Degree or Higher, 1984 and 2004

\begin{tabular}{|l|l|l|}
\hline Age & 1984 & 2004 \\
\hline $25-34$ & $24.3 \%$ & $30.2 \%$ \\
\hline $35-54$ & 22.0 & 30.0 \\
\hline $55-64$ & 14.1 & 28.3 \\
\hline
\end{tabular}

Source: U.S. Census Bureau, Current Population Survey. Available at:

http://www.census.gov/population/www/socdemo/educ-attn.html

Table 2. Three Year Displacement Rates, by Age, 1984-2004

\begin{tabular}{|r|c|c|c|c|c|c|c|c|c|c|c|}
\hline Age & 1984 & 1986 & 1988 & 1990 & 1992 & 1994 & 1996 & 1998 & 2000 & 2002 & 2004 \\
\hline $20-24$ & $15.1 \%$ & $9.8 \%$ & $8.2 \%$ & $7.5 \%$ & $11.6 \%$ & $9.2 \%$ & $9.8 \%$ & $7.9 \%$ & $6.9 \%$ & $10.5 \%$ & 8.1 \\
\hline $25-29$ & 16.1 & 10.3 & 9.5 & 8.4 & 11.7 & 10.4 & 10.2 & 7.8 & 6.5 & 10.0 & 11.0 \\
\hline $30-34$ & 14.2 & 9.9 & 8.9 & 8.2 & 10.3 & 9.7 & 8.8 & 7.4 & 6.7 & 9.7 & 10.8 \\
\hline $35-39$ & 11.7 & 8.6 & 7.7 & 7.1 & 9.7 & 8.7 & 8.9 & 6.9 & 6.2 & 8.6 & 9.3 \\
\hline $40-44$ & 10.1 & 7.4 & 7.4 & 6.5 & 9.0 & 8.7 & 7.9 & 6.8 & 6.5 & 7.3 & 8.8 \\
\hline $45-49$ & 10.1 & 7.1 & 7.0 & 5.8 & 8.8 & 7.6 & 8.3 & 6.4 & 5.7 & 7.7 & 8.3 \\
\hline $50-54$ & 9.2 & 7.2 & 6.6 & 5.5 & 8.6 & 8.1 & 6.9 & 6.4 & 5.7 & 7.3 & 8.0 \\
\hline $55-59$ & 9.5 & 7.3 & 6.7 & 6.0 & 8.7 & 8.6 & 7.2 & 6.9 & 6.5 & 6.9 & 8.5 \\
\hline $60-64$ & 11.1 & 7.8 & 7.5 & 7.4 & 8.8 & 10.1 & 7.3 & 6.7 & 6.7 & 8.1 & 9.4 \\
\hline All & 12.7 & 8.8 & 8.0 & 7.2 & 9.9 & 9.0 & 8.6 & 7.0 & 6.3 & 8.5 & 9.1 \\
\hline
\end{tabular}

Source: Authors' calculations based on the Current Population Survey (1984-2004) and the Displaced Workers Survey (1984-2004). 
Table 3. Reemployment Rates of Displaced Workers, by Age, 1984-2004

\begin{tabular}{|l|c|r|r|r|r|r|r|r|r|r|r|}
\hline Age & 1984 & 1986 & 1988 & 1990 & 1992 & 1994 & 1996 & 1998 & 2000 & 2002 & 2004 \\
\hline $20-24$ & $62.6 \%$ & $63.9 \%$ & $68.0 \%$ & $69.4 \%$ & $56.6 \%$ & $61.1 \%$ & $69.3 \%$ & $72.2 \%$ & $72.1 \%$ & $62.1 \%$ & $62.1 \%$ \\
\hline $25-29$ & 67.0 & 68.3 & 74.7 & 73.5 & 64.7 & 66.5 & 74.2 & 79.0 & 77.9 & 63.9 & 67.8 \\
\hline $30-34$ & 66.2 & 69.6 & 71.3 & 77.0 & 64.0 & 72.1 & 74.8 & 80.4 & 80.0 & 66.7 & 69.5 \\
\hline $35-39$ & 66.6 & 71.5 & 70.3 & 75.2 & 64.3 & 68.1 & 72.8 & 79.0 & 76.4 & 63.6 & 70.2 \\
\hline $40-44$ & 66.4 & 67.9 & 75.2 & 75.9 & 66.5 & 69.1 & 74.9 & 82.0 & 76.1 & 63.8 & 70.9 \\
\hline $45-49$ & 61.3 & 65.9 & 67.3 & 68.9 & 66.0 & 66.8 & 74.8 & 77.5 & 80.2 & 68.8 & 67.2 \\
\hline $50-54$ & 55.5 & 59.2 & 63.1 & 69.6 & 54.6 & 56.7 & 66.7 & 73.4 & 73.7 & 61.7 & 64.5 \\
\hline $55-59$ & 45.2 & 54.7 & 59.9 & 58.7 & 55.4 & 57.0 & 55.4 & 67.2 & 59.0 & 52.3 & 63.3 \\
\hline $60-64$ & 34.4 & 38.6 & 40.7 & 49.2 & 42.1 & 36.7 & 46.7 & 48.6 & 56.6 & 50.3 & 46.3 \\
\hline All & 62.5 & 65.6 & 69.2 & 71.8 & 61.8 & 65.0 & 71.3 & 76.3 & 74.7 & 63.2 & 66.5 \\
\hline
\end{tabular}

Source: Authors' calculations based on the Current Population Survey (1984-2004) and the Displaced Workers Survey (1984-2004).

Table 4. Average Percentage Change in Real Weekly Earnings by Age, 1984-2004

\begin{tabular}{|l|c|c|c|c|c|c|c|c|c|c|c|}
\hline Age & 1984 & 1986 & 1988 & 1990 & 1992 & 1994 & 1996 & 1998 & 2000 & 2002 & 2004 \\
\hline $20-24$ & -14.6 & $-1.8 \%$ & $-1.8 \%$ & $-5.6 \%$ & $-13.3 \%$ & $2.9 \%$ & $3.1 \%$ & $3.8 \%$ & $4.3 \%$ & $-4.6 \%$ & $1.2 \%$ \\
\hline $25-29$ & -15.7 & -7.6 & -7.8 & -4.8 & -13.2 & -4.3 & 5.7 & 3.1 & 4.5 & -5.7 & -13.4 \\
\hline $30-34$ & -12.5 & -13.8 & -12.5 & -9.1 & -13.0 & -7.5 & -3.1 & 3.7 & -1.8 & -15.1 & -16.3 \\
\hline $35-39$ & -19.5 & -13.0 & -17.5 & -8.1 & -26.8 & -12.9 & -8.2 & -11.5 & -1.7 & -5.1 & -14.4 \\
\hline $40-44$ & -22.6 & -18.0 & -16.0 & -13.9 & -23.0 & -20.5 & -13.7 & -4.2 & 0.0 & -14.2 & -30.7 \\
\hline $45-49$ & -18.6 & -14.5 & -15.1 & -10.8 & -27.0 & -21.3 & -15.3 & -10.9 & -10.7 & -12.3 & -28.4 \\
\hline $50-54$ & -25.2 & -27.1 & -30.1 & -29.5 & -24.1 & -21.6 & -12.8 & -6.9 & -5.4 & -20.0 & -37.2 \\
\hline $55-59$ & -24.4 & -44.3 & -25.6 & -22.8 & -28.5 & -31.6 & -21.8 & -24.4 & 0.4 & -10.0 & -22.7 \\
\hline $60-64$ & -43.6 & -15.0 & -59.1 & -5.0 & -38.7 & -41.6 & -23.8 & 0.9 & -7.0 & -20.4 & -31.1 \\
\hline All & -17.4 & -12.9 & -13.8 & -10.0 & -19.7 & -12.6 & -6.6 & -4.4 & -1.7 & -11.1 & -21.0 \\
\hline
\end{tabular}

Source: Authors' calculations based on the Current Population Survey (1984-2004) and the Displaced Workers Survey (1984-2004). 
Table 5. Regression Estimates of the Percent Probability of Being Displaced by Age, 1984-2004

\begin{tabular}{|c|c|c|c|c|c|c|c|c|c|c|c|}
\hline \multicolumn{1}{|l|}{ Age } & 1984 & 1986 & 1988 & 1990 & 1992 & 1994 & 1996 & 1998 & 2000 & 2002 & 2004 \\
\hline $25-29$ & $2.0^{*}$ & $1.1^{*}$ & $1.8^{*}$ & $1.6^{*}$ & $1.0^{*}$ & $2.2^{*}$ & $1.9^{*}$ & $1.2^{*}$ & 0.6 & 0.8 & $4.0^{*}$ \\
\hline $30-34$ & $1.2^{*}$ & $1.3^{*}$ & $1.7^{*}$ & $1.7^{*}$ & 0.0 & $1.8^{*}$ & 0.7 & $1.0^{*}$ & $1.0^{*}$ & $0.9^{*}$ & $4.2^{*}$ \\
\hline $35-39$ & -0.8 & 0.4 & $1.1^{*}$ & $1.2^{*}$ & -0.1 & $1.2^{*}$ & 1.0 & 0.7 & 0.6 & 0.2 & $2.9^{*}$ \\
\hline $40-44$ & $-2.7^{*}$ & $-0.9^{*}$ & 0.9 & $0.9^{*}$ & -0.1 & $1.8^{*}$ & 0.3 & 0.8 & $1.0^{*}$ & $-0.9^{*}$ & $2.5^{*}$ \\
\hline $45-49$ & $-3.3^{*}$ & $-1.3^{*}$ & 0.0 & -0.1 & -0.4 & 0.6 & 1.0 & 0.7 & 0.7 & -0.2 & $2.2^{*}$ \\
\hline $50-54$ & $-3.9^{*}$ & $-1.3^{*}$ & -0.6 & -0.5 & -0.9 & 1.0 & -0.4 & 0.6 & 0.7 & -0.4 & $2.2^{*}$ \\
\hline $55-59$ & $-4.1^{*}$ & $-1.5^{*}$ & -0.7 & -0.1 & -1.1 & $1.4^{*}$ & -0.5 & 0.9 & $1.3^{*}$ & -1.0 & $3.0^{*}$ \\
\hline $60-64$ & $-2.8^{*}$ & $-1.2^{*}$ & 0.0 & 1.0 & -1.2 & $2.7^{*}$ & -0.6 & 0.3 & 1.2 & -0.2 & $3.5^{*}$ \\
\hline
\end{tabular}

Source: Authors' calculations based on the Current Population Survey (1984-2004) and the Displaced Workers Survey (1984-2004).

Note: Table 5 reports for each Displaced Worker Survey the marginal effect of age on the probability of being displaced. The dependent variable is one if a worker reports being displaced in the three years prior to the survey (because of plant closure, position abolished, or slack work) and zero otherwise. The regressions also include indicator variables for female, nonwhite, married, full-time, three of four educational categories (less than high school, some college, college graduate), and two of three industry groups (public sector and private sector goods producing). The omitted age category is 20-24.

Observations are weighted using the Current Population Survey final weights.

Table 6. Regression Estimates of the Percent Probability of Being Displaced with "Tenure" in Equation by Age, 1996-2004

\begin{tabular}{|l|c|c|c|c|c|}
\hline Age & 1996 & 1998 & 2000 & 2002 & 2004 \\
\hline $25-29$ & $3.2^{*}$ & $1.7^{*}$ & $1.1^{*}$ & $1.5^{*}$ & $5.3^{*}$ \\
\hline $30-34$ & $3.1^{*}$ & $2.7^{*}$ & $2.6^{*}$ & $3.0^{*}$ & $6.7^{*}$ \\
\hline $35-39$ & $4.4^{*}$ & $3.2^{*}$ & $2.9^{*}$ & $3.2^{*}$ & $6.8^{*}$ \\
\hline $40-44$ & $4.6^{*}$ & $3.6^{*}$ & $4.2^{*}$ & $2.7^{*}$ & $7.5^{*}$ \\
\hline $45-49$ & $6.1^{*}$ & $4.1^{*}$ & $4.5^{*}$ & $4.1^{*}$ & $8.1^{*}$ \\
\hline $50-54$ & $4.9^{*}$ & $4.7^{*}$ & $4.8^{*}$ & $4.8^{*}$ & $8.7^{*}$ \\
\hline $55-59$ & $5.2^{*}$ & $5.2^{*}$ & $6.1^{*}$ & $4.3^{*}$ & $10.3^{*}$ \\
\hline $60-64$ & $5.2^{*}$ & $5.2^{*}$ & $6.5^{*}$ & $6.1^{*}$ & $11.6^{*}$ \\
\hline
\end{tabular}

Source: Authors' calculations based on the Current Population Survey (1984-2004) and the Displaced Workers Survey (1984-2004).

Note: Table 6 reports for each Displaced Worker Survey the marginal effect of age on the probability of being displaced. The dependent variable is one if a worker reports being displaced in the three years prior to the survey (because of plant closure, position abolished, or slack work) and zero otherwise. In addition to the variables included in Table 5, the regressions include three of four indicator variables for tenure tenure on last job less than a year, tenure 1-4 years, tenure 5-9 years, tenure more than 10 years. The omitted age category is tenure less than 1 year. 
Table 7. Regression Estimates of the Percent Probability of Being Reemployed by Age, 1984-2004

\begin{tabular}{|l|c|c|c|c|c|c|c|c|c|c|c|}
\hline Age & 1984 & 1986 & 1988 & 1990 & 1992 & 1994 & 1996 & 1998 & 2000 & 2002 & 2004 \\
\hline $25-29$ & 0.6 & -1.4 & 2.9 & -0.3 & 3.9 & 1.6 & 2.2 & 5.0 & 2.4 & -0.3 & 3.6 \\
\hline $30-34$ & -2.3 & -1.1 & -2.8 & 3.8 & 2.7 & $7.6^{*}$ & 1.1 & 4.8 & 2.9 & 0.4 & 4.6 \\
\hline $35-39$ & -1.7 & 1.2 & $-6.3^{*}$ & 0.8 & 2.9 & 1.3 & -1.7 & 2.4 & 0.1 & -3.3 & 4.7 \\
\hline $40-44$ & -4.7 & -1.3 & -1.2 & 2.3 & 2.7 & -0.1 & -0.4 & $5.7^{*}$ & -1.5 & -3.4 & 5.3 \\
\hline $45-49$ & -4.9 & -1.3 & $-8.0^{*}$ & -3.9 & 3.8 & -0.5 & -0.5 & 1.1 & 2.9 & 0.5 & 0.4 \\
\hline $50-54$ & $-11.1^{*}$ & -7.3 & $-13.5^{*}$ & -1.4 & $-8.8^{*}$ & $-10.3^{*}$ & $-11.1^{*}$ & -1.7 & -4.8 & $-7.8^{*}$ & -0.8 \\
\hline $55-59$ & $-24.6^{*}$ & $-11.0^{*}$ & $-16.6^{*}$ & $-11.4^{*}$ & -6.9 & $-12.3^{*}$ & $-23.4^{*}$ & $-10.0^{*}$ & $-19.1^{*}$ & $-15.0^{*}$ & -3.4 \\
\hline $60-64$ & $-34.7^{*}$ & $-27.1^{*}$ & $-38.4^{*}$ & $-17.7^{*}$ & $-21.5^{*}$ & $-32.9^{*}$ & $-30.7^{*}$ & $-29.3^{*}$ & $-23.2^{*}$ & $-19.9^{*}$ & $-20.6^{*}$ \\
\hline
\end{tabular}

Source: Authors' calculations based on the Current Population Survey (1984-2004) and the Displaced Workers Survey (1984-2004).

Note: Table 7 reports for each Displaced Worker Survey the marginal effect of age on the probability of being reemployed. The dependent variable is one if a worker reports being displaced in the three years prior to the survey (because of plant closure, position abolished, or slack work) and zero otherwise. The regressions also include indicator variables for female, nonwhite, married, full-time status three of four educational categories (less than high school, some college, college graduate) and two of three industry groups (public sector and private sector goods producing). The omitted age category is 20-24.

Observations are weighted using the Current Population Survey final weights. 
Table 8. Regression Estimates of Percentage Change in Real Weekly Earnings by Age, 1984-2004

\begin{tabular}{|l|c|c|c|c|c|c|c|c|c|c|c|}
\hline Age & 1984 & 1986 & 1988 & 1990 & 1992 & 1994 & 1996 & 1998 & 2000 & 2002 & 2004 \\
\hline $25-29$ & -3.1 & -7.7 & -6.4 & -1.3 & -1.1 & -5.6 & 4.7 & -1.4 & 0.6 & -0.9 & -11.6 \\
\hline $30-34$ & 0.6 & $-15.3^{*}$ & $-11.7^{*}$ & -3.5 & -2.0 & -7.5 & -3.5 & 1.6 & -3.7 & -9.7 & -12.6 \\
\hline $35-39$ & -6.3 & $-14.4^{*}$ & $-15.1^{*}$ & -2.2 & $-14.4^{*}$ & $-11.3^{*}$ & -6.9 & -11.9 & -2.8 & 0.5 & -10.1 \\
\hline $40-44$ & -8.3 & $-17.5^{*}$ & $-12.5^{*}$ & -6.3 & -8.6 & $-17.3^{*}$ & $-10.4^{*}$ & -4.2 & 0.5 & -5.6 & $-25.6^{*}$ \\
\hline $45-49$ & -0.1 & $-11.4^{*}$ & -8.1 & -4.2 & $-12.4^{*}$ & $-15.0^{*}$ & $-10.9^{*}$ & -8.2 & -8.2 & -3.6 & $-21.9^{*}$ \\
\hline $50-54$ & -3.8 & $-23.8^{*}$ & $-21.0^{*}$ & $-18.3^{*}$ & -8.7 & $-15.2^{*}$ & -8.7 & -1.1 & -1.0 & -10.5 & $-26.0^{*}$ \\
\hline $55-59$ & -1.6 & $-36.8^{*}$ & $-15.3^{*}$ & -11.8 & -10.3 & $-19.2^{*}$ & $-15.1^{*}$ & -18.5 & 3.4 & 4.0 & -12.7 \\
\hline $60-64$ & -19.4 & -10.0 & $-45.6^{*}$ & 6.1 & $-21.8^{*}$ & $-37.6^{*}$ & $-19.3^{*}$ & 10.5 & -7.8 & -10.7 & -23.3 \\
\hline
\end{tabular}

Source: Authors' calculations based on the Current Population Survey (1984-2004) and the Displaced Workers Survey (1984-2004).

Note: Table 8 reports the effect of age on the percentage change in real earning by age for each Displaced Worker Survey. The dependent variable is the natural log of real post-displacement earnings minus the natural log of pre-displacement earnings. The regressions also include indicator variables for female, nonwhite, married, full-time status, three of four educational categories (less than high school, some college, college graduate), and two of three industry groups (public sector and private sector goods producing).. The omitted age category is $20-24$. Observations are weighted using the Current Population Survey final weights. 
Table 9. Probability of Displacement, HRS 1994-2004

\begin{tabular}{|c|c|c|c|}
\hline \multirow[t]{2}{*}{ Variable } & With tenure & $\begin{array}{l}\text { With tenure and } \\
\text { pensions }\end{array}$ & $\begin{array}{l}\text { With tenure and } \\
\text { pension detail }\end{array}$ \\
\hline & $\begin{array}{l}\mathrm{dF} / \mathrm{dx} \\
(\mathrm{z} \text {-stat) }\end{array}$ & $\begin{array}{l}\mathrm{dF} / \mathrm{dx} \\
\text { (z-stat) }\end{array}$ & $\begin{array}{l}\mathrm{dF} / \mathrm{dx} \\
(\mathrm{z} \text {-stat) }\end{array}$ \\
\hline Age 50-54 & $\begin{array}{l}.005 \\
(0.60)\end{array}$ & $\begin{array}{l}.007 \\
(0.81)\end{array}$ & $\begin{array}{l}.007 \\
(0.81)\end{array}$ \\
\hline Age 55-59 & $\begin{array}{l}.015 \\
(1.92)\end{array}$ & $\begin{array}{l}.016 \\
(2.06)\end{array}$ & $\begin{array}{l}.016 \\
(2.09)\end{array}$ \\
\hline Age $60-64$ & $\begin{array}{l}.007 \\
(0.87) \\
\end{array}$ & $\begin{array}{l}.006 \\
(0.80)\end{array}$ & $\begin{array}{l}.007 \\
(0.86) \\
\end{array}$ \\
\hline Female & $\begin{array}{l}.001 \\
(0.17)\end{array}$ & $\begin{array}{l}-.002 \\
(-0.48)\end{array}$ & $\begin{array}{l}-.002 \\
(-0.49)\end{array}$ \\
\hline Married & $\begin{array}{l}-.008 \\
(-2.08) \\
\end{array}$ & $\begin{array}{l}.007 \\
(-1.90) \\
\end{array}$ & $\begin{array}{l}.007 \\
(-1.90) \\
\end{array}$ \\
\hline Nonwhite & $\begin{array}{l}-.006 \\
(-1.54)\end{array}$ & $\begin{array}{l}-.006 \\
(-1.66)\end{array}$ & $\begin{array}{l}-.006 \\
(-1.68)\end{array}$ \\
\hline $\begin{array}{l}\text { Less than high } \\
\text { school }\end{array}$ & $\begin{array}{l}.010 \\
(2.46)\end{array}$ & $\begin{array}{l}.007 \\
(1.67)\end{array}$ & $\begin{array}{l}.006 \\
(1.57)\end{array}$ \\
\hline Some college & $\begin{array}{l}.000 \\
(0.05)\end{array}$ & $\begin{array}{l}.001 \\
(0.30)\end{array}$ & $\begin{array}{l}.001 \\
(0.32) \\
\end{array}$ \\
\hline College & $\begin{array}{l}-.009 \\
(-2.18)\end{array}$ & $\begin{array}{l}-.006 \\
(-1.40)\end{array}$ & $\begin{array}{l}-.005 \\
(-1.25)\end{array}$ \\
\hline $\begin{array}{l}\text { Small } \\
\text { establishment size }\end{array}$ & $\begin{array}{l}.011 \\
(2.56)\end{array}$ & $\begin{array}{l}.005 \\
(1.13)\end{array}$ & $\begin{array}{l}.004 \\
(0.89)\end{array}$ \\
\hline $\begin{array}{l}\text { Medium } \\
\text { establishment size }\end{array}$ & $\begin{array}{l}-.007 \\
(-1.87)\end{array}$ & $\begin{array}{l}-.005 \\
(-1.27)\end{array}$ & $\begin{array}{l}-.005 \\
(-1.33)\end{array}$ \\
\hline Tenure: $1-4$ & $\begin{array}{l}-.038 \\
(-9.92)\end{array}$ & $\begin{array}{l}-.033 \\
(-8.35)\end{array}$ & $\begin{array}{l}-.033 \\
(-8.54)\end{array}$ \\
\hline Tenure: 5-9 & $\begin{array}{l}-.054 \\
(-14.14)\end{array}$ & $\begin{array}{l}-.047 \\
(-11.46)\end{array}$ & $\begin{array}{l}-.047 \\
(-11.65)\end{array}$ \\
\hline Tenure: $10+$ years & $\begin{array}{l}-.107 \\
(-22.69)\end{array}$ & $\begin{array}{l}-.088 \\
(-17.58)\end{array}$ & $\begin{array}{l}-.086 \\
(-17.21)\end{array}$ \\
\hline Pension & & $\begin{array}{l}-.031 \\
(-8.29)\end{array}$ & \\
\hline $\mathrm{DB}$ & & & $\begin{array}{l}.035 \\
(-8.48)\end{array}$ \\
\hline DC & & & $\begin{array}{l}-.019 \\
(-5.09)\end{array}$ \\
\hline Both DB and DC & & & $\begin{array}{l}-.027 \\
(-5.91) \\
\end{array}$ \\
\hline Pseudo $\mathrm{R}^{2}$ & .077 & .082 & .083 \\
\hline Observations & 24,659 & 24,482 & 24,659 \\
\hline
\end{tabular}

Note: The equation measures the probability of being displaced for all workers who are employed when they first enter the HRS sample. The equations also include dummy variables for each sample year 19962004 , and the coefficients of these variables are generally statistically significant. 
Table 10. Probability of Working, HRS 1994-2004

\begin{tabular}{|l|l|}
\hline Variable & $\begin{array}{l}\mathrm{dF} / \mathrm{dx} \\
(\mathrm{z}-\mathrm{stat})\end{array}$ \\
\hline Age 50-54 & -.040 \\
& $(-2.40)$ \\
\hline Age 55-59 & -.105 \\
& $(-6.61)$ \\
\hline Age 60-64 & -.272 \\
& $(-16.79)$ \\
\hline Female & -.059 \\
& $(-12.43)$ \\
\hline Married & -.028 \\
& $(-5.02)$ \\
\hline Nonwhite & .003 \\
& $(0.59)$ \\
\hline Less than high & -.018 \\
school & $(-2.79)$ \\
\hline Some college & .015 \\
& $(2.46)$ \\
\hline College & .027 \\
& $(4.40)$ \\
\hline Health & -.204 \\
& $(-31.49)$ \\
\hline Displacement due & -.131 \\
to business closing & $(-9.70)$ \\
\hline Laid off & -.208 \\
& $(-19.46)$ \\
\hline Years since & .008 \\
displacement & $(3.75)$ \\
\hline Years since lay off & .010 \\
& $(6.97)$ \\
\hline & \\
\hline Pseudo R 2 & .110 \\
\hline Observations & 34,839 \\
\hline & \\
\hline & \\
& \\
& \\
& \\
&
\end{tabular}

Note: The equation measures the probability of working for all workers who are employed when they first enter the HRS. The equations also include dummy variables for each sample year 1996-2004, and the coefficients of these variables are generally statistically significant. 
Figure 1. Goods-Producing Employment as a Percent of Total Employment

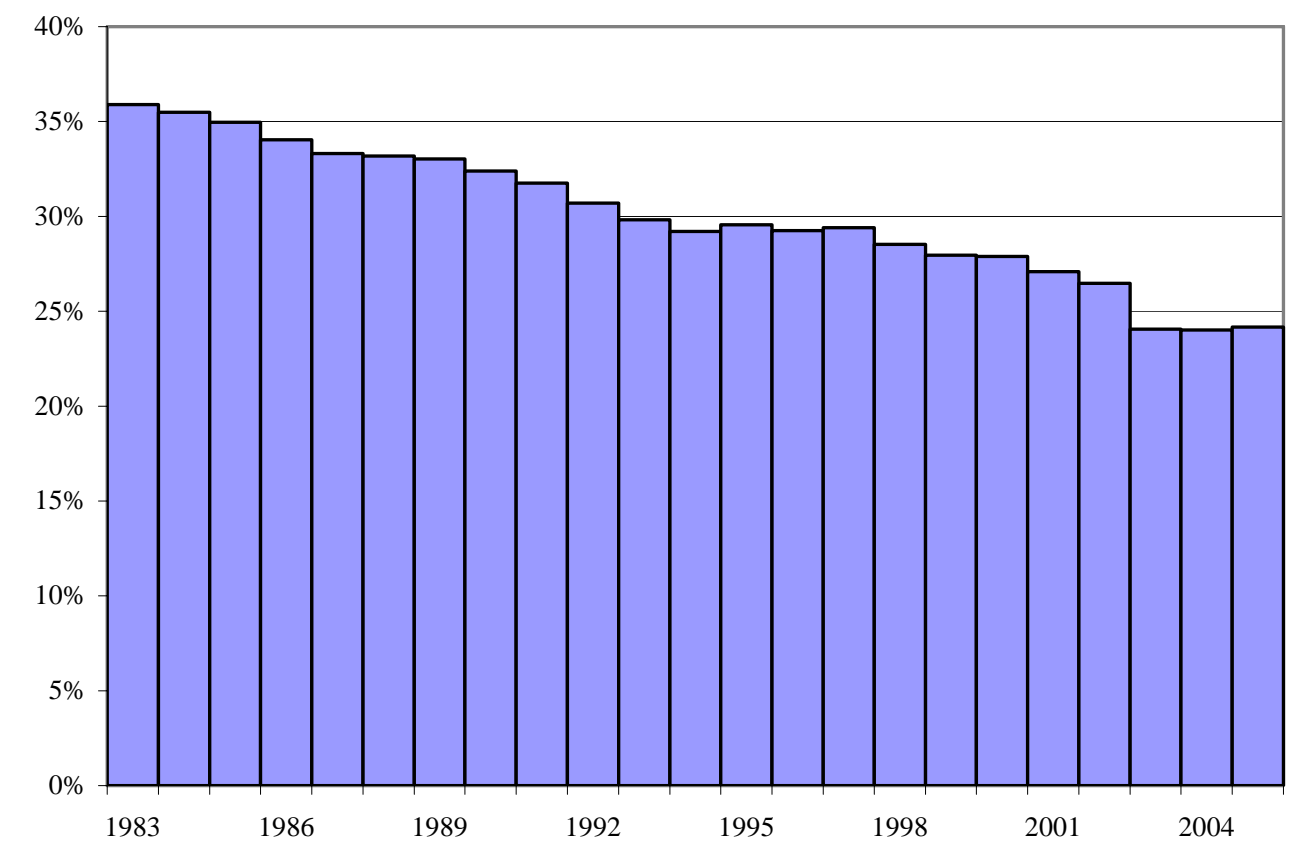

Source: Bureau of Labor Statistics. 2006. Current Employment Statistics Survey 1981-2006.

Note: April, Seasonally adjusted goods producing employment (series CES0600000001) to seasonally adjusted non-farm employment (series CES0600000001). http://www.bls.gov/data/ 
Figure 2. The Percentage of Those with Pension Coverage by Pension Type, 1981-2004

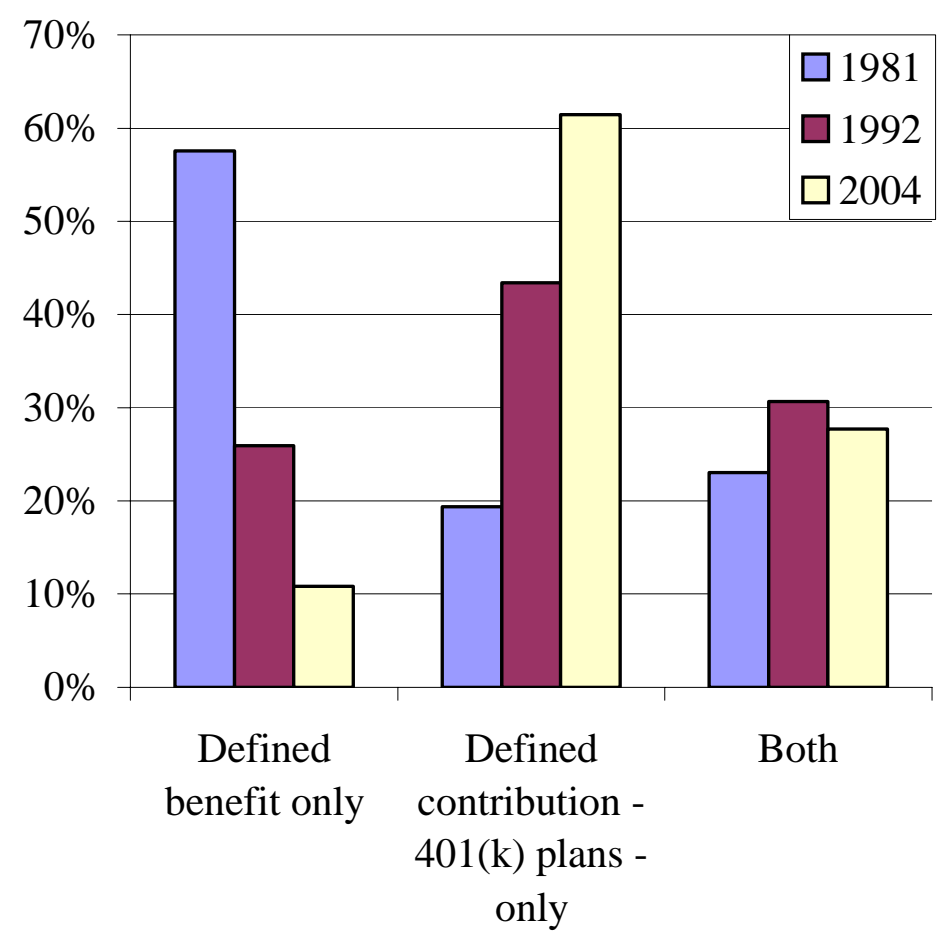

Source: Authors' calculations from Department of Labor Form 5500. 
Figure 3. Percent of Workers Age 55-64 with More than 10, 15, and 20 Years of Tenure, $1983 \& 2004$

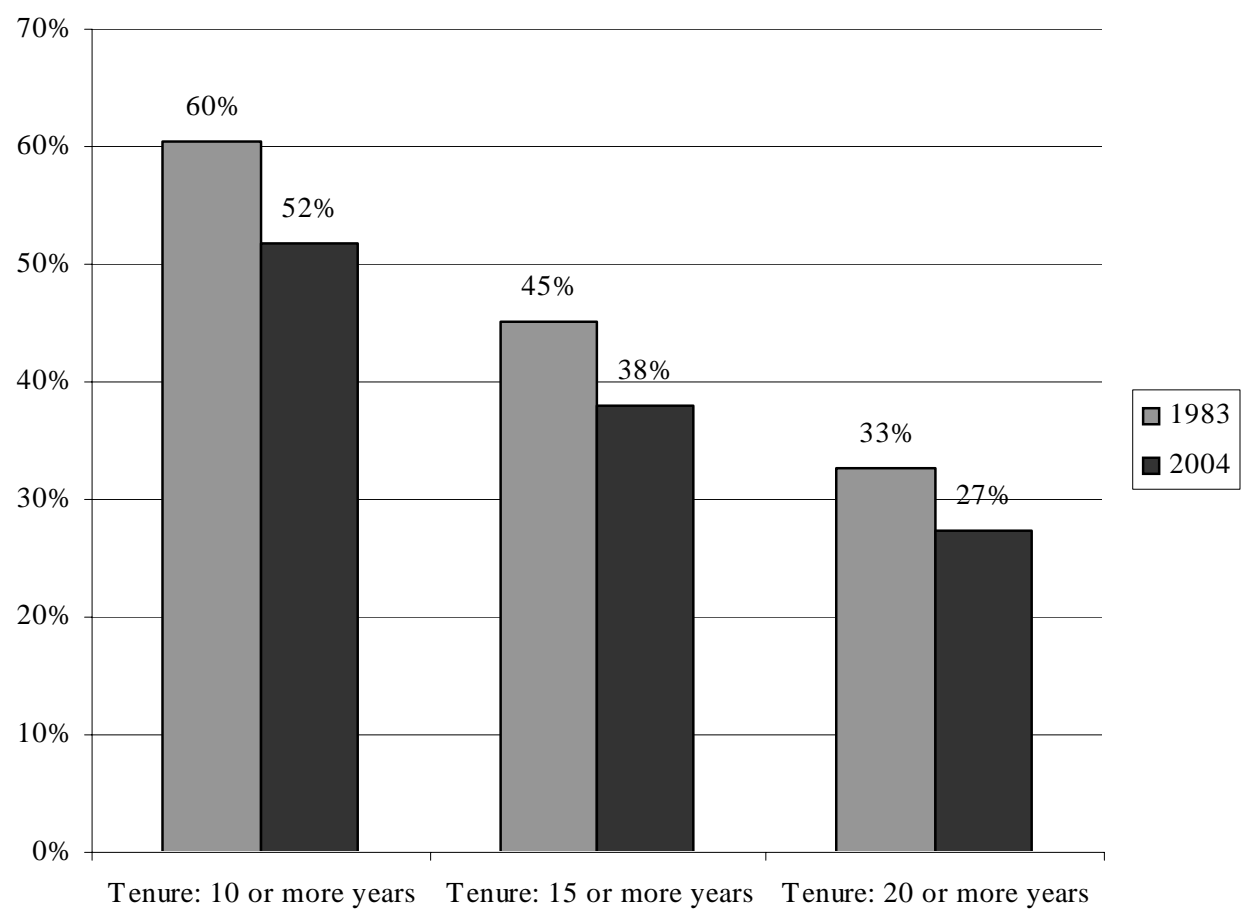

Source: Authors' calculations based on the Current Population Survey. 
Figure 4. Percentage of Workers Displaced by Reason for Displacement, 1984-2004*

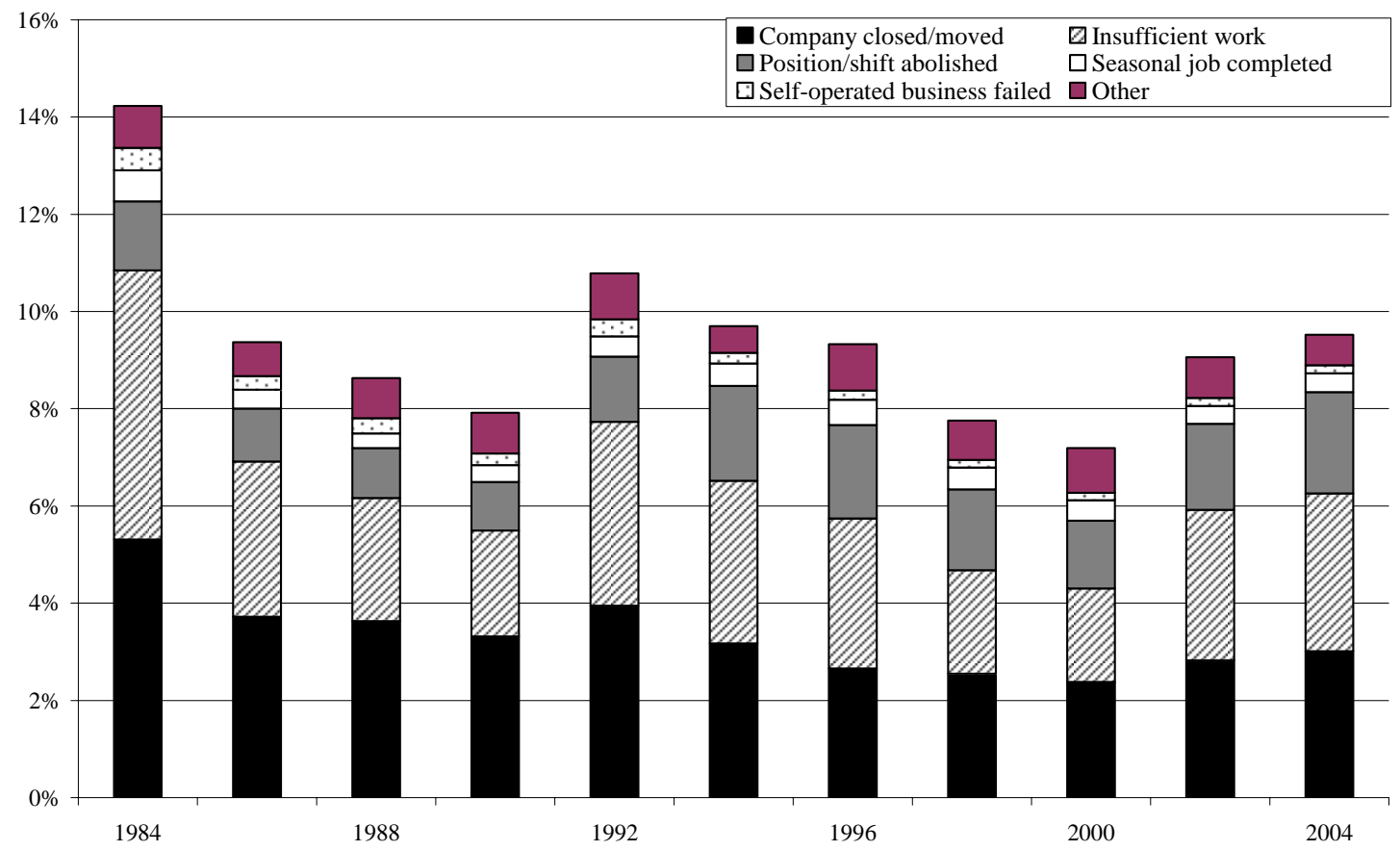

Source: Authors' calculations based on the Current Population Survey (1984-2004) and the Displaced Workers Survey (1984-2004).

Note: The years represent the survey year and are the average of the previous 3 years of data. The "other" category follows Farber (2003) and includes only 25 percent of those losing their jobs for "other" reasons in the 1994 and later surveys and 62 percent of those in the 1992 and earlier surveys. 
Figure 5. Older Displaced Workers as a Percent of Total Displaced Workers, 1984, 1994, and 2004

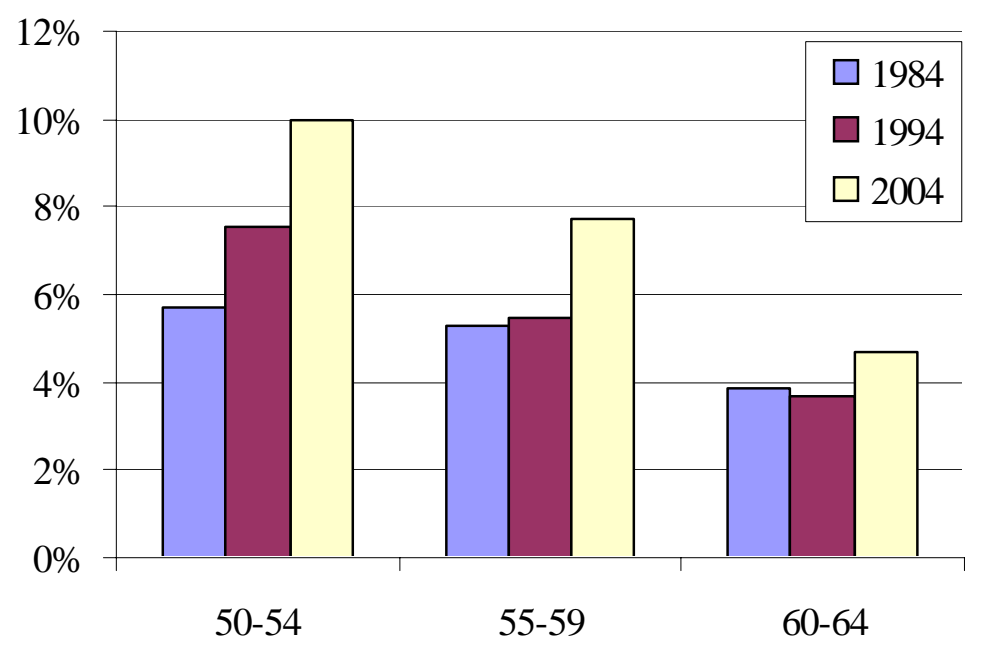

Source: Authors' calculations based on the Current Population Survey (1984-2004) and the Displaced Workers Survey (1984-2004).

Figure 6. Older Workers as a Percent of Total Workforce, 1984, 1994, and 2004

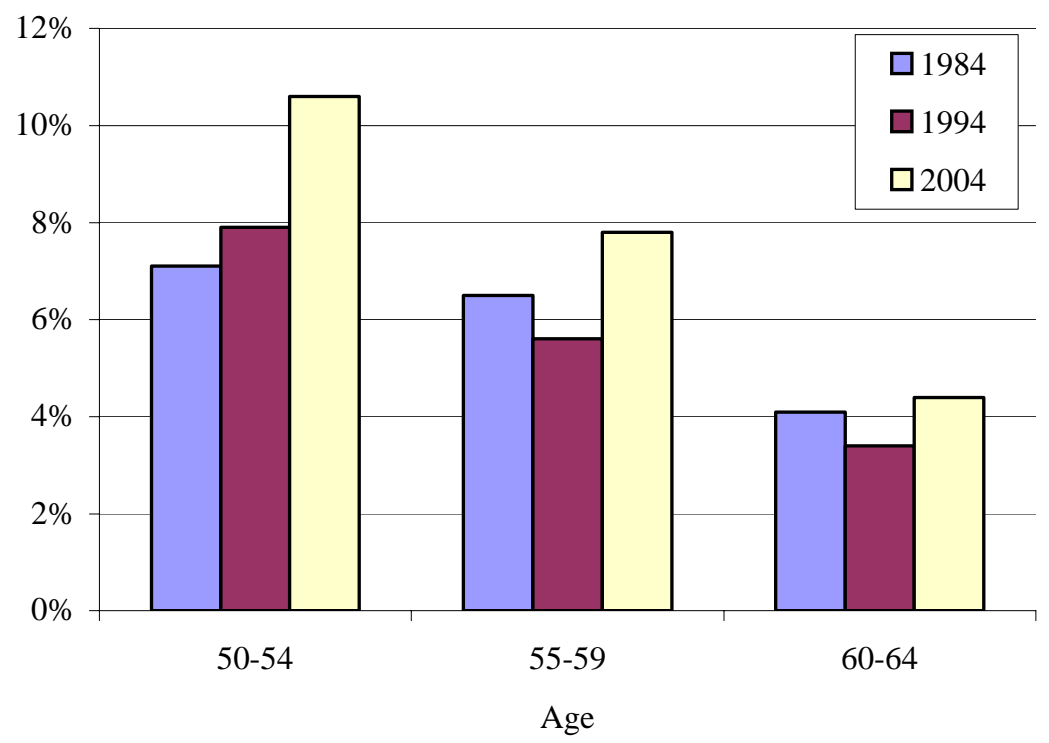

Source: Authors' calculations based on the Current Population Survey (1984-2004). 
Figure 7. Displacement and Unemployment Rates, 1984-2002

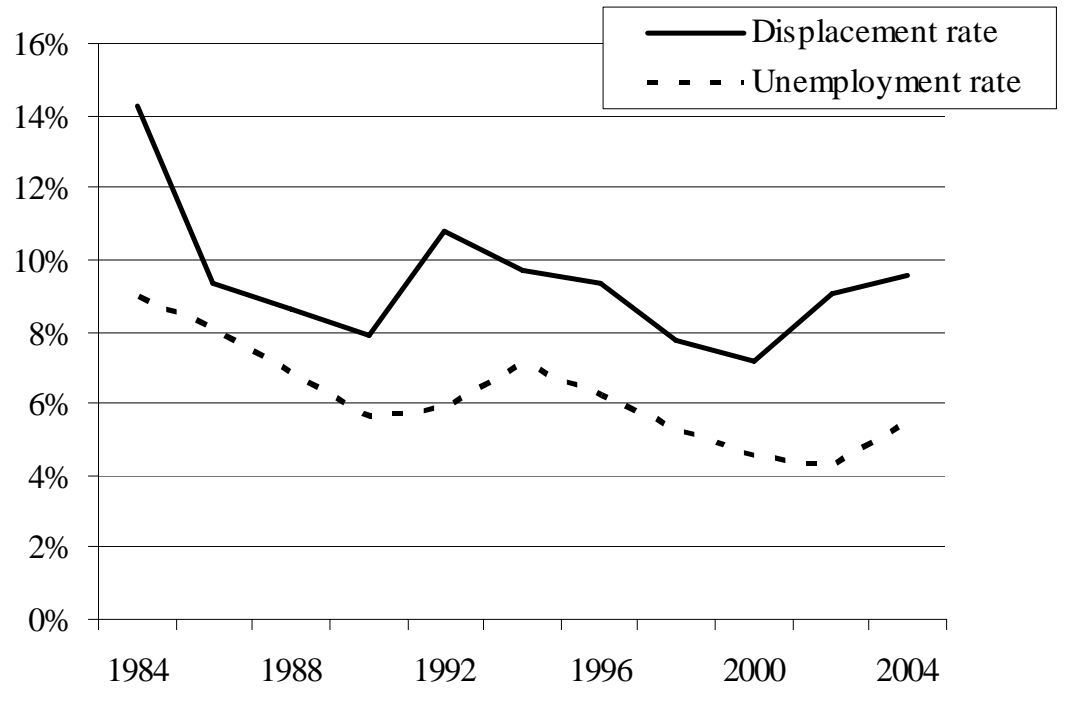

Sources: Authors' calculations based on the Current Population Survey (1984-2004) and the Displaced Workers Survey (1984-2004); and Economic Report of the President. 2006. Washington, DC: United States Government Printing Office.

Note: The average displacement rate for each survey and the three-year unemployment rate for the survey period are shown for the middle year of each survey. That is, for the 2004 survey, which covers 2001, 2002, and 2003, the average unemployment rate for the three-year period and average displacement rate are shown for 2002. 
Figure 8. Reduction in the Probability of Being Displaced Due to College, 1984-2004

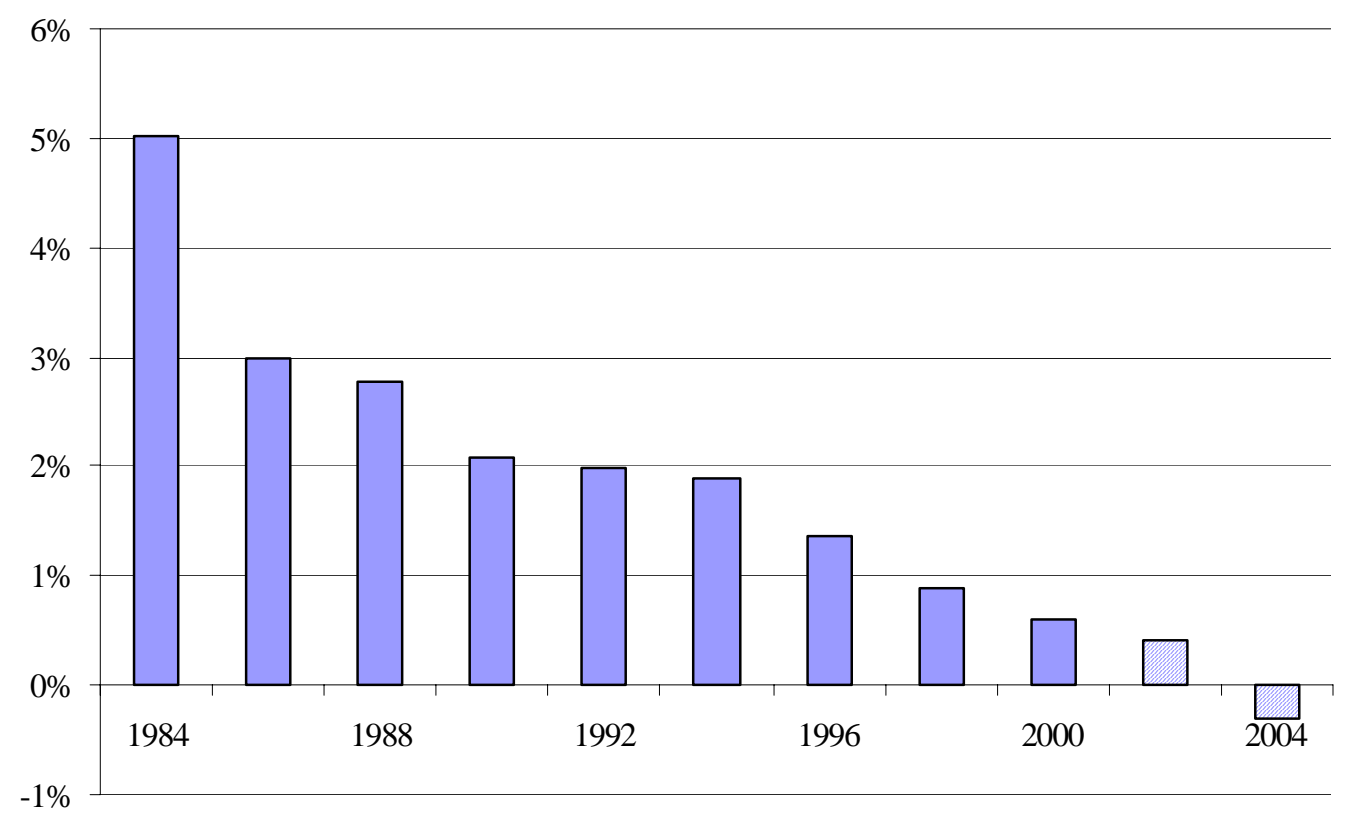

Note: Striped bars indicate results that are not statistically significant.

Source: Authors' calculations based on the Current Population Survey (1984-2004) and the Displaced Workers Survey (1984-2004). 
Figure 9. Reduction in Probability of Displacement by Tenure, 1996-2004

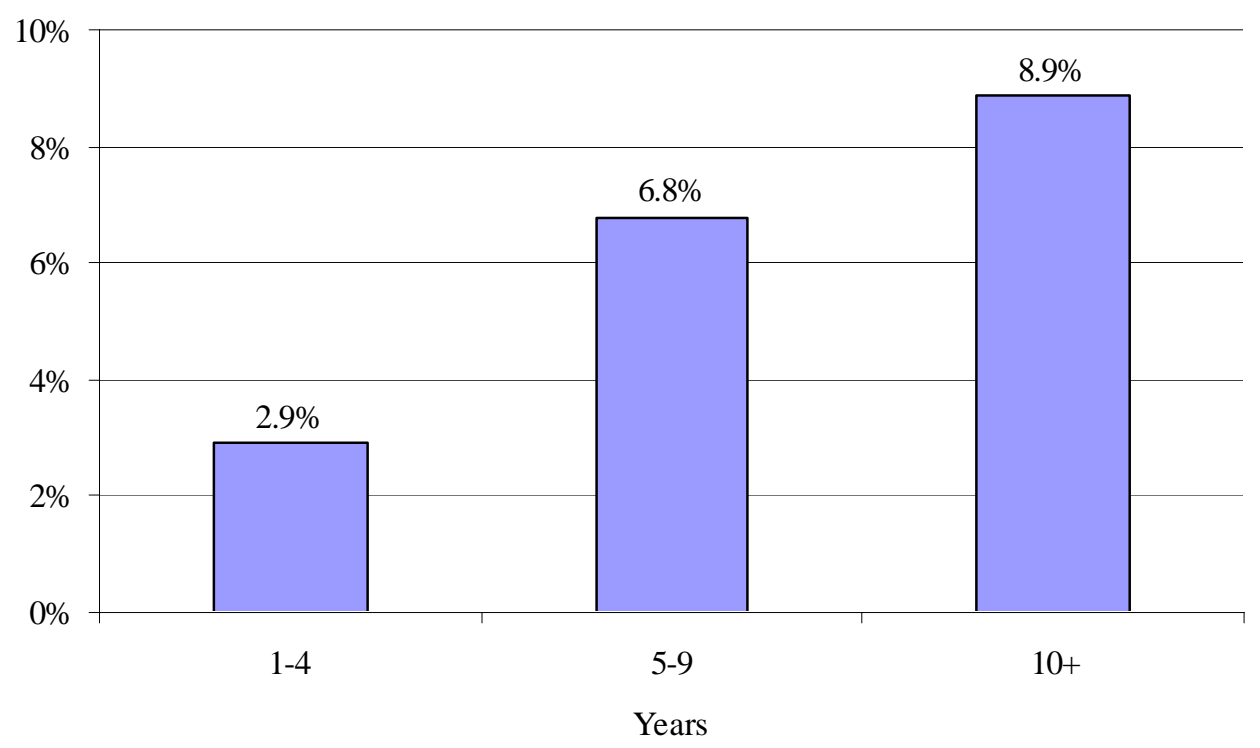

Source: Authors' calculations based on the Current Population Survey (1996-2004) and the Displaced Workers Survey (1996-2004). 
Table A1. Probit Results for the Probability of Displacement

\begin{tabular}{|c|c|c|c|c|c|c|}
\hline \multirow{3}{*}{ Variables } & \multicolumn{2}{|c|}{ Without tenure } & \multicolumn{2}{|c|}{ With tenure } & \multicolumn{2}{|c|}{$\begin{array}{l}\text { With tenure and } \\
\text { pensions }\end{array}$} \\
\hline & $\begin{array}{l}\mathrm{dF} / \mathrm{dx} \\
\text { (z-stat) }\end{array}$ & $\begin{array}{r}\mathrm{dF} / \mathrm{dx} \\
\text { (z-stat) }\end{array}$ & $\begin{array}{l}\mathrm{dF} / \mathrm{dx} \\
\text { (z-stat) }\end{array}$ & $\begin{array}{l}\mathrm{dF} / \mathrm{dx} \\
\text { (z-stat) }\end{array}$ & $\begin{array}{l}\mathrm{dF} / \mathrm{dx} \\
(\mathrm{z}-\mathrm{stat})\end{array}$ & $\begin{array}{l}\mathrm{dF} / \mathrm{dx} \\
\text { (z-stat) }\end{array}$ \\
\hline & 1984 & 2004 & 1996 & 2004 & 1996 & 2004 \\
\hline Age 25-29 & $\begin{array}{r}.020 \\
(4.27)\end{array}$ & $\begin{array}{r}.040 \\
(7.29)\end{array}$ & $\begin{array}{r}.032 \\
(5.35)\end{array}$ & $\begin{array}{r}.053 \\
(8.58)\end{array}$ & $\begin{array}{r}.032 \\
(5.31)\end{array}$ & $\begin{array}{r}.051 \\
(8.43)\end{array}$ \\
\hline Age $30-34$ & $\begin{array}{r}.012 \\
(2.57)\end{array}$ & $\begin{array}{r}.042 \\
(7.50)\end{array}$ & $\begin{array}{r}.031 \\
(5.19)\end{array}$ & $\begin{array}{r}.067 \\
(10.60)\end{array}$ & $\begin{array}{r}.031 \\
(5.12)\end{array}$ & $\begin{array}{r}.065 \\
(10.30)\end{array}$ \\
\hline Age 35-39 & $\begin{array}{r}-.008 \\
(-1.67)\end{array}$ & $\begin{array}{r}.029 \\
(5.25)\end{array}$ & $\begin{array}{r}.044 \\
(7.05)\end{array}$ & $\begin{array}{r}.068 \\
(10.44)\end{array}$ & $\begin{array}{r}.043 \\
(6.94)\end{array}$ & $\begin{array}{r}.066 \\
(10.10)\end{array}$ \\
\hline Age 40-44 & $\begin{array}{r}-.027 \\
(-5.39)\end{array}$ & $\begin{array}{r}.025 \\
(4.76)\end{array}$ & $\begin{array}{r}.046 \\
(7.00)\end{array}$ & $\begin{array}{r}.075 \\
(11.48)\end{array}$ & $\begin{array}{r}.045 \\
(6.86)\end{array}$ & $\begin{array}{r}.072 \\
(10.99)\end{array}$ \\
\hline Age 45-49 & $\begin{array}{r}-.033 \\
(-6.15)\end{array}$ & $\begin{array}{r}.022 \\
(4.01)\end{array}$ & $\begin{array}{r}.061 \\
(8.64)\end{array}$ & $\begin{array}{r}.081 \\
(11.75)\end{array}$ & $\begin{array}{r}.060 \\
(8.48)\end{array}$ & $\begin{array}{r}.076 \\
(11.20)\end{array}$ \\
\hline Age 50-54 & $\begin{array}{r}-.039 \\
(-7.10)\end{array}$ & $\begin{array}{r}.022 \\
(3.90)\end{array}$ & $\begin{array}{r}.049 \\
(6.18)\end{array}$ & $\begin{array}{r}.087 \\
(11.87)\end{array}$ & $\begin{array}{r}.047 \\
(6.00)\end{array}$ & $\begin{array}{r}.081 \\
(11.16)\end{array}$ \\
\hline Age 55-59 & $\begin{array}{r}-.041 \\
(-7.39)\end{array}$ & $\begin{array}{r}.030 \\
(4.79)\end{array}$ & $\begin{array}{r}.052 \\
(5.90)\end{array}$ & $\begin{array}{r}.103 \\
(12.49)\end{array}$ & $\begin{array}{r}.051 \\
(5.73)\end{array}$ & $\begin{array}{r}.095 \\
(11.74)\end{array}$ \\
\hline Age $60-64$ & $\begin{array}{r}-.028 \\
(-4.19)\end{array}$ & $\begin{array}{r}.035 \\
(4.63)\end{array}$ & $\begin{array}{r}.052 \\
(4.88)\end{array}$ & $\begin{array}{r}.116 \\
(11.69)\end{array}$ & $\begin{array}{r}.050 \\
(4.71)\end{array}$ & $\begin{array}{r}.109 \\
(11.08)\end{array}$ \\
\hline Female & $\begin{array}{r}-.021 \\
(-7.65)\end{array}$ & $\begin{array}{r}-.006 \\
(-2.33)\end{array}$ & $\begin{array}{r}-.015 \\
(-5.03)\end{array}$ & $\begin{array}{r}-.009 \\
(-3.31)\end{array}$ & $\begin{array}{r}-.015 \\
(-5.04)\end{array}$ & $\begin{array}{r}-.009 \\
(-3.25)\end{array}$ \\
\hline Married & $\begin{array}{r}-.018 \\
(-5.92)\end{array}$ & $\begin{array}{r}-.021 \\
(-8.40)\end{array}$ & $\begin{array}{r}-.015 \\
(-4.89)\end{array}$ & $\begin{array}{r}-.017 \\
(-6.20)\end{array}$ & $\begin{array}{r}-.015 \\
(-5.03)\end{array}$ & $\begin{array}{r}-.018 \\
(-6.72)\end{array}$ \\
\hline Nonwhite & $\begin{array}{r}.011 \\
(2.83)\end{array}$ & $\begin{array}{r}.010 \\
(3.16)\end{array}$ & $\begin{array}{r}.001 \\
(0.25)\end{array}$ & $\begin{array}{r}.016 \\
(4.68)\end{array}$ & $\begin{array}{r}.001 \\
(0.28)\end{array}$ & $\begin{array}{r}.016 \\
(4.68)\end{array}$ \\
\hline $\begin{array}{l}\text { Less than high } \\
\text { school }\end{array}$ & $\begin{array}{r}.019 \\
(5.07)\end{array}$ & $\begin{array}{r}.013 \\
(2.98)\end{array}$ & $\begin{array}{r}.005 \\
(1.05)\end{array}$ & $\begin{array}{r}.008 \\
(1.82)\end{array}$ & $\begin{array}{r}.006 \\
(1.27)\end{array}$ & $\begin{array}{r}.012 \\
(2.56)\end{array}$ \\
\hline Some college & $\begin{array}{r}-.021 \\
(-6.10)\end{array}$ & $\begin{array}{r}.008 \\
(2.56)\end{array}$ & $\begin{array}{r}.003 \\
(0.75)\end{array}$ & $\begin{array}{r}.006 \\
(1.85)\end{array}$ & $\begin{array}{r}.002 \\
(0.66)\end{array}$ & $\begin{array}{r}.005 \\
(1.57)\end{array}$ \\
\hline College & $\begin{array}{r}-.050 \\
(-14.22)\end{array}$ & $\begin{array}{r}.003 \\
(0.99)\end{array}$ & $\begin{array}{r}-.019 \\
(-5.23)\end{array}$ & $\begin{array}{r}-.001 \\
(-0.34)\end{array}$ & $\begin{array}{r}-.020 \\
(-5.44)\end{array}$ & $\begin{array}{r}-.004 \\
(-1.15)\end{array}$ \\
\hline $\begin{array}{l}\text { Private sector } \\
\text { goods producing }\end{array}$ & $\begin{array}{r}.106 \\
(33.16)\end{array}$ & $\begin{array}{r}.053 \\
(17.22)\end{array}$ & $\begin{array}{r}.039 \\
(11.44)\end{array}$ & $\begin{array}{r}.065 \\
(19.07)\end{array}$ & $\begin{array}{r}.039 \\
(11.22)\end{array}$ & $\begin{array}{r}.065 \\
(19.07)\end{array}$ \\
\hline Public sector & $\begin{array}{r}-.061 \\
(-14.40)\end{array}$ & $\begin{array}{r}-.072 \\
(-20.53)\end{array}$ & $\begin{array}{r}-.056 \\
(-13.54)\end{array}$ & $\begin{array}{r}-.072 \\
(-18.37)\end{array}$ & $\begin{array}{r}-.057 \\
(-13.70)\end{array}$ & $\begin{array}{r}-.074 \\
(-19.05)\end{array}$ \\
\hline Full time & $\begin{array}{r}-.056 \\
(-11.12)\end{array}$ & $\begin{array}{r}-.019 \\
(-5.25)\end{array}$ & $\begin{array}{r}-.020 \\
(-4.72)\end{array}$ & $\begin{array}{r}.000 \\
(-0.10)\end{array}$ & $\begin{array}{r}-.021 \\
(-5.03)\end{array}$ & $\begin{array}{r}-.005 \\
(-1.20)\end{array}$ \\
\hline Tenure: $1-4$ years & & & -.029 & -.037 & -.029 & -.036 \\
\hline
\end{tabular}




\begin{tabular}{|c|c|c|c|c|c|c|}
\hline & & & $(-7.14)$ & $(-9.31)$ & $(-7.08)$ & $(-9.16)$ \\
\hline Tenure: 5-9 years & & & $\begin{array}{r}-.074 \\
(-18.45)\end{array}$ & $\begin{array}{r}-.085 \\
(-22.71)\end{array}$ & $\begin{array}{r}-.074 \\
(-18.41)\end{array}$ & $\begin{array}{r}-.084 \\
(-22.60)\end{array}$ \\
\hline Tenure: $10+$ years & & & $\begin{array}{r}-.096 \\
(-22.70)\end{array}$ & $\begin{array}{r}-.107 \\
(-26.99)\end{array}$ & $\begin{array}{r}-.096 \\
(-22.70)\end{array}$ & $\begin{array}{r}-.106 \\
(-26.82)\end{array}$ \\
\hline Pension coverage & & & & & $\begin{array}{r}.006 \\
(2.13)\end{array}$ & $\begin{array}{r}.019 \\
(7.09)\end{array}$ \\
\hline Pseudo $\mathrm{R}^{2}$ & .073 & .038 & .065 & .080 & .065 & .078 \\
\hline Observations & 56,402 & 55,516 & 40,071 & 50,615 & 40,071 & 49,180 \\
\hline
\end{tabular}

Source: Authors' calculations based on the Current Population Survey (1984-2004) and the Displaced Workers Survey (1984-2004).

Note: Table A1 reports for the 1984, 1996, and 2004 Displaced Worker Survey the marginal effect of age on the probability of being displaced. The dependent variable is one if a worker reports being displaced in the three years prior to the survey (because of plant closure, position abolished, or slack work) and zero otherwise. The regressions also include indicator variables for female, nonwhite, married, and three of four educational categories (less than high school, some college, college graduate). The omitted age category is 20-24. Observations are weighted using the Current Population Survey final weights. 
Table A2. Probit Results for the Probability of Re-employment

\begin{tabular}{|c|c|c|c|}
\hline \multirow[t]{2}{*}{ variables } & \multicolumn{3}{|c|}{$\begin{array}{l}\mathrm{dF} / \mathrm{dx} \\
\text { (z-stat) }\end{array}$} \\
\hline & 1984 & 1996 & 2004 \\
\hline Age $25-29$ & $\begin{array}{r}.006 \\
(0.28)\end{array}$ & $\begin{array}{r}.022 \\
(0.81)\end{array}$ & $\begin{array}{r}.036 \\
(1.26)\end{array}$ \\
\hline Age 30-34 & $\begin{array}{r}-.023 \\
(-0.94)\end{array}$ & $\begin{array}{r}.011 \\
(0.38)\end{array}$ & $\begin{array}{r}.046 \\
(1.63)\end{array}$ \\
\hline Age 35-39 & $\begin{array}{r}-.017 \\
(-0.64)\end{array}$ & $\begin{array}{r}-.017 \\
(-0.59)\end{array}$ & $\begin{array}{r}.047 \\
(1.61)\end{array}$ \\
\hline Age $40-44$ & $\begin{array}{r}-.047 \\
(-1.51)\end{array}$ & $\begin{array}{r}-.004 \\
(-0.14)\end{array}$ & $\begin{array}{r}.053 \\
(1.82)\end{array}$ \\
\hline Age $45-49$ & $\begin{array}{r}-.049 \\
(-1.47)\end{array}$ & $\begin{array}{r}-.005 \\
(-0.15)\end{array}$ & $\begin{array}{r}.004 \\
(0.12)\end{array}$ \\
\hline Age 50-54 & $\begin{array}{r}-.111 \\
(-3.05)\end{array}$ & $\begin{array}{r}-.111 \\
(-2.94)\end{array}$ & $\begin{array}{r}-.008 \\
(-0.25)\end{array}$ \\
\hline Age $55-59$ & $\begin{array}{r}-.246 \\
(-6.44)\end{array}$ & $\begin{array}{r}-.234 \\
(-5.25)\end{array}$ & $\begin{array}{r}-.034 \\
(-0.96)\end{array}$ \\
\hline Age 60-64 & $\begin{array}{r}-.347 \\
(-8.30)\end{array}$ & $\begin{array}{r}-.307 \\
(-5.73)\end{array}$ & $\begin{array}{r}-.206 \\
(-4.88)\end{array}$ \\
\hline Female & $\begin{array}{r}-.115 \\
(-7.37)\end{array}$ & $\begin{array}{r}-.080 \\
(-5.06)\end{array}$ & $\begin{array}{r}-.065 \\
(-4.44)\end{array}$ \\
\hline Married & $\begin{array}{r}.027 \\
(1.75)\end{array}$ & $\begin{array}{r}.030 \\
(1.90)\end{array}$ & $\begin{array}{r}.031 \\
(2.11)\end{array}$ \\
\hline Nonwhite & $\begin{array}{r}-.208 \\
(-9.99)\end{array}$ & $\begin{array}{r}-.134 \\
(-6.18)\end{array}$ & $\begin{array}{r}-.134 \\
(-7.23)\end{array}$ \\
\hline $\begin{array}{l}\text { Less than high } \\
\text { school }\end{array}$ & $\begin{array}{r}-.112 \\
(-6.00)\end{array}$ & $\begin{array}{r}-.098 \\
(-4.00)\end{array}$ & $\begin{array}{r}-.046 \\
(-1.97)\end{array}$ \\
\hline Some college & $\begin{array}{r}.046 \\
(2.36)\end{array}$ & $\begin{array}{r}.029 \\
(1.63)\end{array}$ & $\begin{array}{r}.017 \\
(0.97)\end{array}$ \\
\hline College & $\begin{array}{r}.178 \\
(7.52)\end{array}$ & $\begin{array}{r}.093 \\
(4.43)\end{array}$ & $\begin{array}{r}.066 \\
(3.49)\end{array}$ \\
\hline $\begin{array}{l}\text { Private sector } \\
\text { goods } \\
\text { producing }\end{array}$ & $\begin{array}{r}-.023 \\
(-1.48)\end{array}$ & $\begin{array}{r}-.044 \\
(-2.61)\end{array}$ & $\begin{array}{r}-.043 \\
(-2.74)\end{array}$ \\
\hline Public sector & $\begin{array}{r}-.068 \\
(-1.88)\end{array}$ & $\begin{array}{r}-.013 \\
(-0.38)\end{array}$ & $\begin{array}{r}.044 \\
(1.22)\end{array}$ \\
\hline $\begin{array}{l}\text { Business } \\
\text { closing }\end{array}$ & $\begin{array}{r}-.030 \\
(-1.19)\end{array}$ & $\begin{array}{r}-.005 \\
(-0.24)\end{array}$ & $\begin{array}{r}.030 \\
(1.60)\end{array}$ \\
\hline Slack work & $\begin{array}{r}-.137 \\
(-5.61)\end{array}$ & $\begin{array}{r}-.050 \\
(-2.43)\end{array}$ & $\begin{array}{r}-.004 \\
(-0.23)\end{array}$ \\
\hline
\end{tabular}




\begin{tabular}{|c|c|c|c|}
\hline Tenure & $\begin{array}{r}-.004 \\
(-2.51)\end{array}$ & $\begin{array}{r}.000 \\
(0.32)\end{array}$ & $\begin{array}{r}-.003 \\
(-2.90)\end{array}$ \\
\hline Full-time & $\begin{array}{r}.044 \\
(1.87)\end{array}$ & $\begin{array}{r}.021 \\
(1.04)\end{array}$ & $\begin{array}{r}.050 \\
(2.43)\end{array}$ \\
\hline $\begin{array}{l}\text { Displaced } 2 \\
\text { years ago }\end{array}$ & $\begin{array}{r}.181 \\
(11.21)\end{array}$ & $\begin{array}{r}.131 \\
(7.87)\end{array}$ & $\begin{array}{r}.208 \\
(13.61)\end{array}$ \\
\hline $\begin{array}{l}\text { Displaced } 3 \\
\text { years ago }\end{array}$ & $\begin{array}{r}.219 \\
(12.70)\end{array}$ & $\begin{array}{r}.153 \\
(8.76)\end{array}$ & $\begin{array}{r}.252 \\
(16.05)\end{array}$ \\
\hline Pseudo $\mathrm{R}^{2}$ : & .113 & .076 & .088 \\
\hline Observations & 5,204 & 3,855 & 4,897 \\
\hline
\end{tabular}

Note: Table A2 reports for the 1984, 1996, and 2004 Displaced Worker Survey the marginal effect of age on the probability of being displaced. The dependent variable is one if a worker reports being displaced in the three years prior to the survey (because of plant closure, position abolished, or slack work) and zero otherwise. In addition to the variables included in Table 5, the regressions include three of four indicator variables for tenure - tenure on last job less than a year, tenure 1-4 years, tenure 5-9 years, tenure more than 10 years. The omitted age category is tenure less than 1 year. 
Table A3. OLS Results for Real Weekly Earnings Change, 1984, 1996, and 2004

\begin{tabular}{|c|c|c|c|}
\hline \multirow[t]{2}{*}{ Variable } & \multicolumn{3}{|c|}{$\begin{array}{l}\text { Coefficient } \\
\text { (t-stat) }\end{array}$} \\
\hline & 1984 & 1996 & 2004 \\
\hline \multirow[t]{2}{*}{ Age $25-29$} & -.031 & .047 & -.116 \\
\hline & $(-0.80)$ & $(1.01)$ & $(-1.28)$ \\
\hline \multirow[t]{2}{*}{ Age $30-34$} & .006 & -.035 & -.126 \\
\hline & $(0.15)$ & $(-0.72)$ & $(-1.40)$ \\
\hline \multirow[t]{2}{*}{ Age $35-39$} & -.063 & -.069 & -.101 \\
\hline & $(-1.36)$ & $(-1.44)$ & $(-1.09)$ \\
\hline \multirow[t]{2}{*}{ Age 40-44 } & -.083 & -.104 & -.256 \\
\hline & $(-1.57)$ & $(-2.03)$ & $(-2.81)$ \\
\hline \multirow[t]{2}{*}{ Age 45-49 } & -.001 & -.109 & -.219 \\
\hline & $(-0.02)$ & $(-2.12)$ & $(-2.31)$ \\
\hline \multirow[t]{2}{*}{ Age 50-54 } & -.038 & -.087 & -.260 \\
\hline & $(-0.54)$ & $(-1.42)$ & $(-2.53)$ \\
\hline \multirow[t]{2}{*}{ Age 55-59 } & -.016 & -.151 & -.127 \\
\hline & $(-0.21)$ & $(-2.11)$ & $(-1.15)$ \\
\hline \multirow[t]{2}{*}{ Age 60-64 } & -.194 & -.193 & -.233 \\
\hline & $(-1.94)$ & $(-2.02)$ & $(-1.63)$ \\
\hline \multirow[t]{2}{*}{ Female } & -.045 & .004 & -.016 \\
\hline & $(-1.58)$ & $(0.17)$ & $(-0.38)$ \\
\hline \multirow[t]{2}{*}{ Married } & .120 & .023 & -.023 \\
\hline & (4.36) & $(0.94)$ & $(-0.54)$ \\
\hline \multirow[t]{2}{*}{ Nonwhite } & .014 & -.026 & .082 \\
\hline & $(0.35)$ & $(-0.75)$ & (1.49) \\
\hline \multirow{2}{*}{$\begin{array}{l}\text { Less than high } \\
\text { school }\end{array}$} & -.098 & .020 & .022 \\
\hline & $(-2.85)$ & $(0.49)$ & $(0.31)$ \\
\hline \multirow[t]{2}{*}{ Some college } & -.011 & -.017 & -.106 \\
\hline & $(-0.34)$ & $(-0.57)$ & $(-2.04)$ \\
\hline \multirow[t]{2}{*}{ College } & .035 & -.032 & -.074 \\
\hline & $(0.92)$ & $(-1.01)$ & $(-1.40)$ \\
\hline \multirow{2}{*}{$\begin{array}{l}\text { Private sector } \\
\text { goods } \\
\text { producing }\end{array}$} & -.106 & -.044 & -.006 \\
\hline & $(-3.93)$ & $(-1.75)$ & $(-0.13)$ \\
\hline \multirow[t]{2}{*}{ Public sector } & .094 & .073 & .148 \\
\hline & (1.58) & (1.38) & (1.37) \\
\hline \multirow{2}{*}{$\begin{array}{l}\text { Displaced due } \\
\text { to business } \\
\text { closing }\end{array}$} & .093 & .036 & .052 \\
\hline & (2.27) & $(1.21)$ & (1.03) \\
\hline Displaced due & .029 & .049 & .025 \\
\hline
\end{tabular}




\begin{tabular}{|l|r|r|r|}
\hline to slack work & $(0.70)$ & $(1.57)$ & $(0.47)$ \\
\hline $\begin{array}{l}\text { Displaced two } \\
\text { years ago }\end{array}$ & $\begin{array}{r}.035 \\
(1.15)\end{array}$ & $\begin{array}{r}-.003 \\
(-0.10)\end{array}$ & $(0.85)$ \\
\hline $\begin{array}{l}\text { Displaced three } \\
\text { years ago }\end{array}$ & -.010 & -.032 & .042 \\
& $(-0.31)$ & $(-1.11)$ & $(0.85)$ \\
\hline Tenure on & -.016 & -.010 & -.012 \\
previous job & $(-5.79)$ & $(-5.32)$ & $(-3.34)$ \\
\hline Constant & -.136 & .028 & .006 \\
& $(-2.57)$ & $(0.56)$ & $(0.06)$ \\
\hline & & & 1,988 \\
\hline $\mathrm{R}^{2}:$ & 1,610 & 1,613 & \\
\hline Observations & & & .058 \\
\hline
\end{tabular}

Source: Authors' calculations based on the Current Population Survey (1984-2004) and the Displaced Workers Survey (1984-2004).

Note: Table A3 reports the effect of age on the percentage change in real earnings by age for the 1984, 1996, and 2004 Displaced Worker Survey. The dependent variable is the natural log of real post-

displacement earnings minus the natural log of pre-displacement earnings. The regressions also include indicator variables for female, nonwhite, married, and three of four educational categories (less than high school, some college, college graduate). The omitted age category is 20-24. Observations are weighted using the Current Population Survey final weights. 


\section{RECENT WORKING PAPERS FROM THE \\ CENTER FOR RETIREMENT RESEARCH AT BOSTON COLLEGE}

No Place Like Home: Older Adults and their Housing

Timothy Smeeding, Barbara Boyle Torrey, Jonathan Fisher, David S. Johnson, and Joseph Marchand, August 2006

Effects of Public Policies on the Disposition of Lump-Sum Distributions: Rational and Behavioral Influences

William G. Gale and Michael Dworsky, August 2006

Pensions, Social Security, Wealth and Lifetime Earnings: Evidence from the Health and Retirement Study

William G. Gale and John W.R. Phillips, August 2006

Determinants and Consequences of Bargaining Power in Households

Leora Friedberg and Anthony Webb, June 2006

Earnings and Women's Retirement Security

Alicia H. Munnell and Natalia Zhivan, June 2006

Mortality Heterogeneity and the Distributional Consequences of Mandatory

Annuitization

Guan Gong and Anthony Webb, June 2006

Can Heterogeneity of Populations Explain Differences in Mortality?

James W. Vaupel, Roland Rau, Carlo Giovanni Camarda and Kristin G. von Kistowski, March 2006

Personalized Retirement Advice and Managed Accounts: Who Uses Them and How Does Advice Affect Behavior in 401(k) Plans?

Julie Agnew, March 2006

Working for a Good Retirement

Barbara A. Butrica, Karen E. Smith and C. Eugene Steuerle, March 2006

The Politics of Parallel Pensions: Lessons from the United Kingdom for the United States

R. Kent Weaver, February 2006

All working papers are available on the Center for Retirement Research website (http://www.bc.edu/crr) and can be requested by e-mail (crr@bc.edu) or phone (617-552-1762). 